\title{
LAS MUTACIONES DE LA CONSTITUCIÓN PRODUCIDAS POR VÍA INTERPRETATIVA DEL TRIBUNAL CONSTITUCIONAL. ¿EL TRIBUNAL CONSTITUCIONAL PODER CONSTITUIDO O PODER CONSTITUYENTE EN SESIÓN PERMANENTE?
}

\author{
Humberto Nogueira Alcalá ${ }^{1}$ \\ Profesor Derecho Constitucional, \\ Universidad de Talca, Chile \\ nogueira@utalca.cl
}

\section{INTRODUCCIÓN}

El Tribunal Constitucional emitió su sentencia Rol $N^{\circ} 1.288-2008$, de veinticinco de agosto de dos mil nueve, en control preventivo obligatorio de Constitucionalidad sobre la Ley Adecuatoria de la Ley Orgánica Constitucional del mismo Tribunal Constitucional, luego de ocho meses de estudio de la misma.

En este artículo nos remitiremos a analizar solo el tema de control reparador de tratados que merece análisis crítico de dicho fallo. Este aspecto es el referente a la declaración de inconstitucionalidad del artículo 47 b) que el artículo $N^{\circ} 57$ del proyecto introduce al Párrafo $6^{\circ}$ del Título II del Capítulo II de la Ley $\mathrm{N}^{\circ} 17.997$, cuyo epígrafe es "Cuestiones de Inaplicabilidad", establece que "de conformidad con el número 1) del artículo 54 de la Constitución Política de la República, no procederá la inaplicabilidad respecto de tratados internacionales ratificados por Chile y que se encuentren vigentes.". Asimismo, el texto del proyecto de LOC adecuatoria de la LOCTC, en el artículo $47 \mathrm{G}$, precisa que el artículo único, $\mathrm{N}^{\circ} 57$, del proyecto incorpora al mismo

1 El autor es Doctor en Derecho, Universidad Católica de Lovaina la Nueva, Bélgica. Diplomado en Derecho Internacional de los Derechos Humanos. Profesor Titular de Derecho Constitucional y Director del Centro de Estudios Constitucionales de Chile de la Universidad de Talca. Presidente de la Asociación Chilena de Derecho Constitucional. Vicepresidente del Instituto Iberoamericano de Derecho Procesal Constitucional. Miembro Asociado de la Academia Internacional de Derecho Comparado. Artículo enviado el 10 de septiembre de 2009. 
párrafo, en su inciso primero, $\mathrm{N}^{\circ} 4^{\circ}$, que procederá declarar la inadmisibilidad "cuando se promueva (la cuestión) respecto de un precepto que no tenga rango legal o respecto de disposiciones de un tratado internacional vigente". El tema central es así procedencia de la acción inaplicabilidad en materia de tratados internacionales.

Cabe dejar constancia que en dicho fallo sobre la materia adoptada fue aprobado por seis votos (Ministros Bertelsen; Correa; Navarro; Fernández, Mario; Venegas y Vodanovic) con cuatro votos disidentes (Ministros Colombo, Cea, Peña y Fernández, Francisco), como asimismo, con un voto de la mayoría que realiza una prevención importante sobre la materia (Ministro Navarro).

\section{LAS DISPOSICIONES CONSTITUCIONALES RELEVANTES PARA LA MATERIA ANALIZADA}

El artículo $6^{\circ}$, inciso $1^{\circ}$ de la Constitución, determina que: "Los órganos del Estado deben someter su acción a la Constitución y a las normas dictadas conforme a ella, y garantizar el orden institucional de la República". El inciso $2^{\circ}$ agrega que "Los preceptos de esta Constitución obligan tanto a los titulares o integrantes de dichos órganos como a toda persona, institución o grupo".

El artículo $7^{\circ}$ de la Constitución en su inciso $1^{\circ}$, precisa que "Los órganos del Estado actúan válidamente previa investidura regular de sus integrantes, dentro de sus competencia y en la forma que prescriba la ley". El inciso $2^{\circ}$ determina que "Ninguna magistratura, ninguna persona o grupo de personas puede atribuirse, ni aún a pretexto de circunstancias extraordinarias, otra autoridad o derechos que los que expresamente se le hayan conferido en virtud de la Constitución o las leyes". Termina el inciso $3^{\circ}$ de la disposición señalando que "Todo acto en contravención a este artículo es nulo y originará las responsabilidades y sanciones que la ley señale".

De acuerdo al artículo $32, \mathrm{~N}^{\circ} 15$, de la Constitución, es de resorte exclusivo del Presidente de la República "conducir las relaciones políticas con las potencias extranjeras..., y llevar a cabo las negociaciones; concluir, firmar y ratificar los tratados que estime convenientes para los intereses del país...".

El artículo $54 \mathrm{~N}^{\circ} 1^{\circ}$, inciso $1^{\circ}$, de la Constitución, norma que fue objeto de reforma constitucional el año 2005, establece la facultad exclusiva del Congreso Nacional para aprobar o desechar los tratados internacionales que le presente el Presidente de la República antes de su ratificación. En el inciso primero "in fine", indica que la aprobación del tratado en el Congreso "se someterá, en lo pertinente, a los trámites de una ley", haciendo la diferencia con el antiguo artículo 50 de la Constitución, que no indicaba "en lo pertinente".

El artículo $54 \mathrm{~N}^{\circ} 1$, inciso $5^{\circ}$ de la Constitución, introducido por la reforma constitucional de 2005, precisa “Las disposiciones de un tratado solo podrán ser derogadas, 
modificadas o suspendidas en la forma prevista en los propios tratados o de acuerdo a las normas generales de derecho internacional".

El artículo 63 de la Constitución establece taxativamente las materias de ley en sus veinte numerales.

El inciso primero del artículo 66 de la Constitución Política de la República expresa que "las normas legales que interpreten preceptos constitucionales necesitarán, para su aprobación, modificación o derogación, de las tres quintas partes de los diputados y senadores en ejercicio".

Conforme a lo establecido en el artículo 92, inciso final, de la Constitución, agregado por la reforma constitucional de 2005, respecto del Tribunal Constitucional: "Una ley orgánica constitucional determinará su organización, funcionamiento, procedimientos y fijará la planta, régimen de remuneraciones y estatuto de su personal".

El artículo 92 de la Constitución establece un Tribunal Constitucional, cuyas atribuciones taxativas están explicitadas en el artículo 93 de la Constitución.

El artículo 93, inciso primero, $\mathrm{N}^{\circ} 1^{\circ}$ de la Carta Fundamental establece el control preventivo obligatorio de constitucionalidad, para las disposiciones contenidas en leyes interpretativas de la Constitución, en leyes orgánicas constitucionales y en "un tratado que versen sobre materias propias de estas últimas".

El artículo 93, inciso primero, $\mathrm{N}^{\circ} 3$ ) ha considerado la posibilidad de deducir cuestiones de constitucionalidad tanto respecto de "proyectos de ley, de reforma constitucional y de tratados sometidos a la aprobación del Congreso." Si ambos tipos de normas -ley y tratado- hubieren sido de la misma naturaleza, habría bastado utilizar la expresión genérica de "ley".

El artículo 93, inciso primero, $\mathrm{N}^{\circ} 6$, de la Ley Suprema confía a esta Magistratura la atribución de "resolver, por la mayoría de sus miembros en ejercicio, la inaplicabilidad de un precepto legal cuya aplicación en cualquier gestión que se siga ante un tribunal ordinario o especial, resulte contraria a la Constitución."

El inciso undécimo de esa misma disposición precisa, por su parte, que: "En el caso del número $6^{\circ}$, la cuestión podrá ser planteada por cualquiera de las partes o por el juez que conoce del asunto. Corresponderá a cualquiera de las salas del Tribunal declarar, sin ulterior recurso, la admisibilidad de la cuestión siempre que verifique la existencia de una gestión pendiente ante el tribunal ordinario o especial, que la aplicación del precepto legal impugnado pueda resultar decisivo en la resolución de un asunto, que la impugnación esté fundada razonablemente y se cumplan los demás requisitos que establezca la ley. A esta misma sala le corresponderá resolver la suspensión del procedimiento en que se ha originado la acción de inaplicabilidad por inconstitucionalidad". 


\section{ANÁLISIS CRÍTICO DE LA INTERPRETACIÓN MUTATIVA DEL TEXTO CONSTITUCIONAL DESARROLLADA POR EL FALLO DEL TRIBUNAL CONSTITUCIONAL}

\subsection{Algunas consideraciones básicas de hermenéutica constitucional}

Como señala Gadamer, "la interpretación no es un acto complementario a la comprensión, sino que comprender es siempre interpretar y, en consecuencia, la interpretación es la forma explícita de la comprensión".²

Asimismo, nos recuerda Hesse, que "comprender y, con ello concretizar sólo es posible con respecto a un problema concreto. El intérprete tiene que poner en relación con dicho problema la norma que pretende entender, si quiere determinar su contenido correcto aquí y ahora". ${ }^{3}$

La interpretación es siempre concreta, ella se ejercita cuando se está ante un caso o problema que requiere una decisión, determinando el sentido y alcance de los enunciados normativos.

Canotilho señala que "interpretar una norma constitucional es atribuir un significado a uno o varios símbolos lingüísticos escritos en la Constitución con el fin de obtener una resolución de problemas prácticos, normativa-constitucionalmente fundados". ${ }^{4}$

La interpretación constitucional necesariamente parte y concluye en lo jurídico considerando los valores y principios que establece el ordenamiento, constituyendo la reflexión jurídica más profunda.

Ascarelli nos dirá que el objeto de la interpretación no es la norma sino solo un texto, ${ }^{5}$ el enunciado normativo; la norma es el producto interpretativo del intérprete al resolver el caso específico, la norma nace en el momento en que se concreta el producto de la interpretación jurídica, determinando el contenido de la norma aplicable. ${ }^{6}$

El resultado interpretativo busca solucionar jurídicamente un caso que es jurídico constitucional, de modo que la juridicidad de la interpretación se garantiza por el caso jurídico y la perspectiva jurídica en su resolución.

\footnotetext{
GadAmer, H.G. 1984. Verdad y método, Ed. Sígueme, Salamanca, p. 382.

HesSE, Konrad. 1992. Escritos de derecho constitucional. Centro de Estudios Constitucionales, Madrid, p. 42. Canotilho, J.J. 2000. Direito Constitucional. Ed. Almedina, Coimbra, p. 143.

5 Ascarell, T. 1959. Interpretazione y giurisprudenza Costituzionale, en Probleme giuridici, Ed. Giuffrè, Milán, p. 140.

6 LAREnz, Karl. 1980. Metodología de la ciencia del derecho, Ariel, Barcelona, p. 308.
} 
La tarea de interpretación jurídica se encuentra institucionalizada y se desarrolla en el plano de la racionalidad práctica, sobre la cual existen exigencias formales y sustanciales o materiales.

Una vez determinadas los enunciados constitucionales que forman el caso, deben aplicarse los enunciados hermenéuticos, para identificar el sentido preciso de las disposiciones en dicha hipótesis concreta, aplicándose el o los enunciados constitucionales abstractos al caso concreto.

La letra de la Constitución es el punto de partida y límite del intérprete. El texto constituye el punto de referencia obligado, es lo primero a lo que se aproxima el intérprete para encontrar una solución al problema planteado.

La letra del enunciado normativo es siempre el punto de referencia obligatorio para el intérprete, cualquiera sea la norma objeto de interpretación, constitucional, legal, administrativa o contractual. Asimismo, la formulación lingüística de la norma constituye el límite externo para cualquier variación de sentido jurídico constitucionalmente posible, como señala Wroblewski. ${ }^{7}$

La Constitución, a su vez, constituye un cuerpo sistemático de normas de máximo rango que utilizan un lenguaje sintético o de textura abierta que establecen valores, principios y reglas.

A su vez, la amplitud y textura abierta de algunas de las normas constitucionales posibilita su actualización, lo que hace que la interpretación constitucional no sólo cumpla una función de presupuesto de aplicación de un enunciado normativo, sino también en elemento de renovación y actualización del orden jurídico, ${ }^{8}$ adaptándose a las nuevas realidades y valores vigentes, haciéndose dúctil a las nuevas contingencias, como asimismo posibilita la promoción de consensos políticos dentro de ciertos límites.

El intérprete constitucional requiere tener "voluntad de Constitución", como señalaba Hesse, para que la Carta Fundamental adquiera y conserve su realización práctica, incentivando asimismo la formación de lo que Lucas Verdú denominó sentimiento constitucional, vale decir, un vínculo moral de los ciudadanos con su ordenamiento constitucional.

El intérprete constitucional debe estar dotado de "voluntad de Constitución" como precisa Hesse, ella se sostiene en tres vertientes: a) la comprensión de la necesidad y del valor del orden normativo constitucional que protege contra la arbitrariedad; b) la comprensión de que el orden constitucional requiere un constante proceso de legiti-

WróblewsKI, Jerzy. Constitución y teoría general de la interpretación jurídica, p. 225.

8 Alonso García, E. 1986. La interpretación de la Constitución, Centro de Estudios Constitucionales, Madrid, p. 1. 
mación; c) la conciencia de que ese orden constitucional no lograra ser eficaz sin el concurso de las voluntades humanas, adquiriendo y manteniendo su vigencia a través de tales actos de voluntad.

Puede decirse que hay "voluntad de constitución", cuando la Carta Fundamental se transforma en fuerza efectiva cuando las tareas que ella establece son efectivamente realizadas por los destinatarios de las respectivas normas, los cuales adecuan sus conductas al orden constitucional establecido.

El intérprete constitucional debe ajustarse a principios y a ciertas reglas que en su conjunto conforman el método para la hermenéutica constitucional, que es de clara naturaleza jurídica. ${ }^{9}$

El objeto de la interpretación constitucional es encontrar el resultado constitucionalmente correcto a través de un procedimiento racional y controlable, el intérprete utilizará todos los elementos que le permitan dar la mejor solución al problema que debe resolver.

A su vez, la concretización o realización del contenido del enunciado normativo constitucional tiene como presupuesto necesario la incorporación de las circunstancias de la realidad ya previstas en su comando. La singularidad de tales circunstancias, señala Hesse, "integran el ámbito normativo, el cual, a partir del conjunto de los datos del mundo social afectados por un precepto, a través del mandato contenido sobre todo en el texto de la norma, el programa normativo es elevado a parte integrante del contenido normativo". ${ }^{10}$

Uno de los deberes de los operadores de las constituciones que tratan de aplicar rectamente los enunciados normativos que requieren de interpretación es considerar en la decisión las consecuencias políticas de la decisión aún cuando deben estar asentados en fundamentos jurídicos objetivos normativos.

El problema y los elementos de la norma constitucional vinculan al intérprete. El programa normativo y el ámbito normativo actúan como límites específicos y directrices que la Constitución contiene en orden a la aplicación, coordinación y valoración de dichos elementos en el curso de la solución del problema. ${ }^{11}$

Los principios de interpretación constitucional se consideran principios constitucionales ya que en su esencia los contienen, por lo tanto, son en sí mismos principios constitucionales. $^{12}$

\footnotetext{
Alonso García, E. 1986. La interpretación, cit. nota n. 8, p. 519.

10 Hesse, Konrad. Escritos, cit. nota n. 3, p. 29.

11 Hesse, Konrad. Escritos, cit. nota n. 3, p. 46.

12 CRISAfulu, V. 1939. I principi costituzionali dell'interpretazione delle leggi, Ed. Cedam, Padua.
} 
La interpretación constitucional es una interpretación sistemática que interpreta los enunciados normativos atendiendo a su posición dentro de la Constitución o el ordenamiento jurídico, evitando perspectivas excluyentes y utilizando todos los métodos de interpretación para obtener la solución correcta.

Esta analiza la relación de unas normas con otras a partir de su ubicación y estructura dentro del texto normativo o complejo normativo. Este método analiza la coherencia de contenidos entre los diferentes enunciados normativos (formales o materiales), sin reducir la sistematicidad a la pura posición que ocupa el enunciado normativo en el ordenamiento jurídico. La comprensión a través de la interpretación sistemática se encuentra en la relación que guarda el enunciado normativo con los otros enunciados normativos del ordenamiento jurídico en su conjunto.

Todas las normas constitucionales deben ser interpretadas en su conjunto, ellas no constituyen un conjunto de normas yuxtapuestas, lo que excluye la interpretación de una norma a partir de sí misma o en forma aislada, el intérprete debe equilibrar las eventuales tensiones entre ellas, debiendo armonizar las diversas disposiciones o enunciados normativos y superar los eventuales espacios de tensión entre normas constitucionales de acuerdo con los valores y principios establecidos en ella. La Constitución constituye en cuanto unidad un conjunto con sentido lógico y teleológico, siendo un orden unitario que rige la vida de la sociedad política.

Las constituciones construyen un sistema ordenado y unitario estructurado por el constituyente en forma racional en el que se encuentra distribuidas todas las materias que contiene, lo que, a su vez, implica aceptar o desechar significados a los enunciados normativos dependiendo de su ubicación topográfica en el texto.

Aquí surge una de las particularidades de la interpretación constitucional que es la imperatividad de considerar a la Constitución como un todo, como un sistema coherente e interrelacionado de principios y reglas estructuradas con visión unitaria, la interpretación sistemática es un mandato del ámbito constitucional a partir de la unidad de la Constitución. Jamás pueden tomarse e interpretarse normas o enunciados normativos aislados o considerados como suficientes en sí mismos. Todos los enunciados normativos constitucionales están imbricados entre sí y traspasados por una unidad de sentido.

La unidad de la Constitución implica que "todas las normas constitucionales han de ser interpretadas de tal manera que se eviten contradicciones con otras normas constitucionales. única solución del problema coherente con este principio es la que se encuentra en consonancia con las decisiones básicas de la Constitución y evite su limitación unilateral a aspectos parciales". ${ }^{13}$

Otro postulado de interpretación constitucional básico es el de otorgamiento de máxima eficacia o efecto útil a los enunciados normativos constitucionales, exige al

13 HesSe, Konrad. Escritos, cit. nota. n. 3, p. 48. 
intérprete dirigirse hacia aquellas alternativas que "optimicen o maximicen la eficacia de las normas constitucionales, sin distorsionar su contenido", ${ }^{14}$ como asimismo, sin dejar de integrar en el análisis todos los componentes del texto constitucional. Luchaire señala que "cuando una disposición es susceptible de dos sentidos, es preferible entenderla en aquel que le permite tener algún efecto antes que en el sentido con el cual no podría producir ninguno". ${ }^{15}$ Ninguna disposición constitucional puede considerarse inútil. A todas las normas y vocablos debe otorgárseles un efecto útil y eficaz y debe ser armonizado con los demás preceptos normativos. Toda interpretación que ignore preceptos o vocablos constitucionales representa una forma de violación de la Constitución y atenta contra el postulado de unidad de la Constitución.

El principio de armonización o concordancia práctica exige al intérprete el deber de superar las eventuales tensiones entre normas dándole la eficacia y optimización que cada una de ellas tiene en el caso concreto, para lo cual debe atribuir un significado a las normas que no sea contradictorio con otros principios y reglas constitucionales.

Asimismo, exige que el intérprete otorgue a cada precepto una interpretación coherente con las demás principios y reglas constitucionales, dándole a cada uno el máximo de aplicación y fuerza normativa, buscando el mejor equilibrio posible, la mayor optimización posible. Cada uno de los enunciados normativos y partes de la Constitución deben entenderse a la luz de todas las demás normas que la integran. Este principio en cuanto tal no dice nada sustantivo, sólo indica una dirección y determina el procedimiento a través del cual debe buscarse la solución constitucional.

La Constitución consagra las decisiones políticas fundamentales del Estado, configurando una fórmula y orden político consensuado, como asimismo determinado constitucionalmente. ${ }^{16}$ Ello implica darle a cada órgano la función y atribuciones que le corresponde y el ámbito de relaciones institucionales diseñado por la Constitución. El intérprete de la Constitución debe facilitar y no obstaculizar o bloquear el desarrollo de las actividades regulares de los órganos mientras estas se mantengan dentro de la fórmula política diseñada por la Carta Fundamental, impidiendo las invasiones ilegítimas de unos órganos o autoridades en el ámbito propio de otros de ellos, tratando de alterar el sistema de frenos y contrapesos establecidos.

La Carta Fundamental debe asegurar el funcionamiento regular de las instituciones, lo que exige que cada órgano desarrolle sus funciones y atribuciones dentro del marco constitucional y de acuerdo a la forma política y jurídica de Estado y gobierno determinada constitucionalmente.

La interpretación conforme a la Constitución. El intérprete y aplicador de las normas infraconstitucionales, de acuerdo a este postulado de interpretación conforme a

14 Pérez LuÑo, Antonio. 1986. Derechos Humanos, Estado de Derecho y Constitución, p. 278.

15 Luchaire, F. 1981. "De la méthode en droit constitutionnel, en Revue du Droit Public, Paris, p. 294.

16 Ver el estudio detenido de este enfoque en, CANOSA USERA, Raúl. 1988. Interpretación constitucional y fórmula política. Ed. Centro de Estudios Constitucionales, Madrid. 
la Constitución, debe optar entre las diversas alternativas de interpretación posible de la norma subconstitucional que la haga más compatible con la Carta Fundamental, excluyendo toda interpretación incompatible con la Constitución.

La interpretación conforme a la Constitución es un método y técnica de interpretación jurídica que busca aquella interpretación más armoniosa y coherente con la Carta Fundamental, entre las diversas interpretaciones posibles que el precepto normativo admita. Esta línea interpretativa elimina toda interpretación del precepto que conduzca a un resultado contrastante o contrario con la Carta Fundamental. Este postulado es una consecuencia directa del carácter de norma suprema, de norma unitaria y de la fuerza normativa de la Constitución. De aquí se deriva la interpretación sistemática de la Constitución. ${ }^{17}$

Este postulado no solo constituye un enfoque interpretativo, sino que en la práctica constituye una forma implícita de control de constitucionalidad en la medida que desecha por ilegítima la o las lecturas de la norma jurídica infraconstitucional que se considere contraria a la Constitución.

Ella se aplica tanto a normas jurídicas infraconstitucionales, postconstitucionales y preconstitucionales, lo que implica que el derecho preconstitucional debe adaptarse a la nueva situación constitucional, pudiendo ser invalidado si no se encuentra en armonía con el texto constitucional vigente

La interpretación conforme a la Constitución posibilita una renuncia al formalismo jurídico y a las interpretaciones convencionales en nombre de la justicia sustantiva y de la seguridad jurídica.

La interpretación conforme a la Constitución lleva a una interpretación favor legis en el ámbito del derecho interno, y de favor convenciones, en el plano del derecho internacional, vale decir, opera una presunción de constitucionalidad de la obra del legislador y del gobierno al aprobar una ley o un tratado internacional. ${ }^{18}$ Sólo podrá declarar inconstitucional un precepto legal si en ninguna de sus interpretaciones posibles es compatible con la Constitución. Los preceptos legales sólo serán declarados inconstitucionales cuando exista una contradicción manifiesta entra la Carta Fundamental y la ley, ya que en caso de duda la presunción favorece la constitucionalidad del precepto legal. El principio de "interpretación conforme a la Constitución" tiene como supuestos el respeto a la obra del legislador democrático quien tiene, de acuerdo a las Cartas Fundamentales del Constitucionalismo democrático, la facultad de con-

17 Ver Meorla Chierchia, P. 1978. L'interpretazione sistematica della Costituzione, Ed Cedam, Padua, p. 201.

18 Sentencia del Tribunal Constitucional de fecha 4 de agosto de 2000 , Rol $\mathrm{N}^{\circ} 309$, sobre Convenio $N^{\circ} 169$ sobre Pueblos Indígenas y Tribales en países independientes, donde el Tribunal Constitucional hace un esfuerzo de interpretación conforme a la Constitución, declarando constitucional el acuerdo aprobatorio del Convenio. 
figurar el ordenamiento jurídico, para lo cual al elaborar el precepto legal pretende siempre respetar la Ley Fundamental que es la Constitución, como asimismo, el supuesto de la separación de poderes o la distribución de la potestad estatal entre los diversos órganos y funciones, correspondiéndole al parlamento la tarea de configurar el ordenamiento jurídico, tarea que está vedada a la jurisdicción constitucional. En todo caso, estos argumentos hay que considerarlos como presunciones de iuris tantum, en la medida que posibilitan la prueba en contrario.

Así, si un enunciado legal conduce a diferentes alternativas de aplicación, debe preferirse siempre aquella que salvaguarde la integridad constitucional del precepto legal, así las sentencias atípicas de los tribunales constitucionales conocidas como sentencias condicionadas, sentencias interpretativas o sentencias de conformidad con la Constitución, excluyendo algunas interpretaciones inconstitucionales de una ley, se basan precisamente en el respeto máximo posible de presunción de constitucionalidad de la obra del legislador, evitando dentro de lo posible el generar un vacío legal. Estas sentencias son aquellas en que el juez constitucional restringe el alcance normativo de la norma infraconstitucional, limitando su aplicación o limitando sus efectos, lo que implica expulsar del ordenamiento jurídico una o más interpretaciones de la ley, manteniendo la eficacia normativa de esta en aquella interpretación que es conforme a la Carta Fundamental, en otras palabras, que no es contraria a la Constitución, evitando así el traumatismo de la eliminación de la ley del ordenamiento jurídico con el consiguiente vacío normativo y todas sus consecuencias.

Los operadores jurídicos tienen la obligación de interpretar y aplicar el derecho internacional válidamente incorporado al derecho interno, de acuerdo a los principios de buena fe y cumplimiento de las obligaciones válidamente contraídas por el Estado. Así la jurisdicción ordinaria y constitucional debe hacer el esfuerzo máximo de armonizar las normas de fuente interna con las normas incorporadas al derecho interno y de fuente internacional, evitando al Estado incurrir en responsabilidad internacional, especialmente si tenemos presente que las normas internacionales son de aplicación preferente y ellas no pueden dejarse sin efecto sino sólo a través de los procedimientos contemplados en el derecho internacional, como determina el artículo 54 inciso $5^{\circ}$ de nuestra Carta Fundamental.

El intérprete no debe perder nunca de vista las consecuencias de sus interpretaciones y decisiones. La Constitución como lo ha señalado la Jurisprudencia de la Corte Suprema norteamericana no es un "pacto suicida", sino un pacto que hace posible y perfectible la convivencia dentro de la sociedad política, debiendo la interpretación favorecer la supervivencia y prosperidad de la sociedad política que ella regula. Es aplicable en este ámbito la consideración de que el derecho constitucional no es un fin en sí mismo, es un instrumento de gobierno para el bien común de la sociedad y el intérprete constitucional debe tener presente el adagio proveniente del derecho romano de que a veces el summun ius puede constituirse en una summa injuria.

El operador de la Constitución debe interpretar previsoramente teniendo presente las consecuencias de su decisión para el caso concreto y para el conjunto de la socie- 
dad (bien común), lo que, a su vez, otorga razonabilidad al fallo o sentencia, al ponderar los intereses sociales y particulares.

El Tribunal Constitucional más que ningún otro Tribunal debe extremar la fundamentación argumentativa de sus sentencias. En esta perspectiva se distinguen tres parámetros básicos de control de la argumentación del intérprete, verificando la validez y corrección de la argumentación al momento de la adopción de la decisión. En el caso de la interpretación constitucional la argumentación cumple un rol clave y muchas veces determinante, por ello la demostración lógica del raciocinio desarrollado y la fundamentación de las diversas opciones adoptadas en el proceso de adoptar la decisión jurisdiccional son de especial importancia para determinar la legitimidad de la decisión y el control de ella.

El primero especifica que la argumentación debe basarse en enunciados normativos constitucionales que le otorguen sustento, ya que el órgano jurisdiccional sólo está autorizado para imponer una conducta que se encuentre fundada en el ordenamiento jurídico a través de una argumentación explícita, debiendo la decisión jurisdiccional estar fundada en los hechos y el derecho.

El órgano jurisdiccional debe permitir, a través de su línea argumental, que las partes puedan conocer las razones en virtud de las cuales optó en determinada dirección y no en otras.

La motivación de las sentencias es especialmente importante en materia de jurisdicción constitucional, donde debe explicitarse la argumentación que conduce cada paso o etapa y, finalmente, la decisión, posibilitando su adecuado control racional y jurídico.

El segundo parámetro está dado por la posibilidad de universalizar los criterios adoptados en la decisión jurisdiccional, pudiendo los mismos criterios ser aplicados a casos análogos, lo que posibilita el control de inconsistencias y desvíos por parte del órgano jurisdiccional.

El tercer parámetro que posibilita el control de la argumentación jurídica está dado por el uso de los principios y valores que contempla el orden constitucional y de los postulados específicos de interpretación constitucional. Estos postulados y principios señalan el camino por donde debe transitar el intérprete, ya que ante diversas opciones posibles, deberá seguir aquella que se encuentre más conforme con los postulados específicos de interpretación constitucional y realizar en la forma de mayor optimización los principios y valores constitucionales.

Con ello no se agota el problema, ya que la selección de los hechos relevantes del caso y la determinación de los enunciados constitucionales que se utilizarán para hacer surgir la norma para el caso concreto no son evidentes.

Por otra parte, en algunas oportunidades, se puede acudir a premisas que no pueden ser extraídas del derecho positivo, sino de elementos extra sistémicos, lo que 
hace aun más necesaria y de mayor importancia la fundamentación externa, que debe justificar las premisas que el juez adoptó como base de su razonamiento; como señala Alexy el aspecto más trascendente de la justificación interna del razonamiento jurídico es que permite que las premisas no extraídas del derecho positivo aparezcan con toda claridad. ${ }^{19}$

Lo que nos interesa precisar, al margen de los diversos problemas que presenta la justificación de las decisiones jurídicas, es que la justificación representa un elemento vertebral para definir la posición institucional del intérprete del derecho, donde la actuación racional es la fuente de su legitimidad. Los jueces deben responder por la forma en que desarrollan su actividad y su control se ejerce mediante la crítica de la fundamentación racional de sus resoluciones, para lo cual sus decisiones deben encontrarse suficientemente motivadas en forma sincera y transparente en términos racionales y comunicables a la comunidad.

En un Estado Constitucional Democrático, el derecho como señalara Perelman, es "fruto de la persuasión y de la razón, ha de obtener mediante la motivación una adhesión razonada". ${ }^{20}$

La motivación de las sentencias no es, como sostiene Prieto Sanchís, un acto de cortesía ni un ejercicio académico, sino que es una obligación de todo tribunal, en especial de los tribunales constitucionales, ya que no solo constituye una exposición razonada de los fundamentos que llevaron a adoptar la resolución, sino que también constituye adicionalmente "una reconstrucción de algún aspecto o sector del sistema jurídico". ${ }^{21}$

La idoneidad de los argumentos que sustentan la resolución jurisdiccional se encuentra directamente vinculada a la aceptabilidad de la decisión, lo que exige una cuidadosa y adecuada expresión de las razones idóneas que la justifiquen con el objeto de contribuir a la pacificación y al convencimiento de la sociedad que recibe tales resoluciones judiciales.

Es necesario precisar que como señala Orrú, "La legitimidad democrática de las valoraciones realizadas por el juez dependen de la transparencia de sus opciones axiológicas, porque cuando las mismas no son explícitas, no pueden ser criticadas ni sometidas a verificación pública”. ${ }^{22}$

Una decisión jurisdiccional de inconstitucionalidad estará justificada si procede de un razonamiento que respete las reglas de la lógica y de la argumentación jurídica. Al

19 ALEXY, R. 1989. Teoría de la argumentación jurídica, Ed. Centro de Estudios Constitucionales, Madrid, p. 220.

20 Perelman, Ch. 1990. Ethique et droit. Ed. De L'Université de Bruxelles, Bruxelles, p. 679.

21 Prieto Sanchís, Luis. 2005. "Notas sobre la interpretación constitucional". En Ferrer Mac-Gregor, Eduardo. 2005. Interpretación Constitucional, Ed. Porrúa, México, D.F., p. 939.

22 ORRú, Giovanni. 1998. Rechterecht. Il problema della liberta e autoritá giudiziale nella dotrina tudesca contemporanea. Ed. Giuffrè, Milán, p. 17. 
respecto, Atienza precisa que una decisión es racional si respeta las reglas de la lógica deductiva, así como los principios de la racionalidad práctica, entre los cuales se cuentan la consistencia, la coherencia, la generalización y la sinceridad. ${ }^{23}$

Las sentencias deben cumplir las exigencias básicas de racionalidad, las cuales han sido sistematizados por las diversas teorías de la argumentación jurídica, ${ }^{24}$ entre ellos se encuentran los criterios que tienen mayor respaldo doctrinal, ellos son los siguientes:

a) Claridad y consistencia conceptual. La claridad conceptual significa que los argumentos utilizados puedan ser comprendidos por la comunidad jurídica y política, siguiendo las reglas lingüísticas y gramaticales de la comunidad. La consistencia conceptual se refiere a la coherencia de los conceptos, atribuyéndole siempre a los mismos conceptos iguales significados.

b) Consistencia normativa. Debe ante hechos análogos utilizarse los mismos argumentos que puedan justificar los mismos resultados interpretativos. La aplicación de los mismos argumentos con resultados interpretativos diferentes debe ser justificada.

c) Respeto de la lógica deductiva. Las decisiones constitucionales serán más racionales mientras más respete las reglas de la lógica deductiva.

d) Consistencia argumentativa y coherencia. La decisión será más racional cuando sea coherente desde el punto de vista argumentativo en cuanto con más respaldo cuente en reglas, principios y valores, o en premisas analíticas que sustenten otras proposiciones del mismo sistema.

e) Consistencia con las fuentes del derecho vigente. La decisión debe fundarse en las fuentes del derecho vigente, respetando los principios de jerarquía, competencia o aplicación preferente según sea el caso.

Dichas reglas orientan el trabajo interpretativo y las decisiones jurisdiccionales, como asimismo como criterios que permiten analizar los fallos de los tribunales, ${ }^{25}$ considerando tanto más racionales dichas sentencias cuanto más se satisfagan los criterios de racionalidad. ${ }^{26}$

El principio de razonabilidad constituye una orientación ineludible pero plástica como presupuesto epistemológico, ello le da sentido al ordenamiento, sin anular el sentido crítico que se impone como principio de toda interpretación.

23 Puede consultarse: Mazzarese, T. 1996. Forme di racionalita delle decisión giudiziali. Ed. Giappichelli. Torino. Atienza, M. 1991. Las razones del derecho. Teorías de la argumentación jurídica. Ed. Centro de Estudios Constitucionales, Madrid. Alexy, R. 1989. Teoría de la argumentación jurídica. Ed. Centro de Estudios Constitucionales, Madrid.

24 Ver, Atienza, M. 1991. Las razones del derecho. Teorías de la argumentación jurídica. Centro de Estudios Constitucionales, Madrid.

25 Al respecto puede consultarse, VV.AA. 1994. Ragionevolezza nella giurisprudenza della Corte Costituzionale. Ed. Giuffrè, Milán.

26 Bernal Pulido, Carlos. 2005. El derecho de los derechos. Ed. Universidad Externado de Colombia, Bogota, p. 65. 
Así, la teoría constitucional, la teoría de la argumentación jurídica y la interpretación constitucional son ámbitos fundamentales que deben internalizarse adecuadamente para realizar una correcta y plausible tarea de interpretación constitucional y de emisión de fallos en el ámbito de la jurisdicción constitucional.

Sólo de esta forma se concretará una adecuada interpretación y aplicación de la Constitución, sin que la jurisdicción constitucional del Estado Constitucional pueda ser considerada como un menoscabo del Estado Democrático, ${ }^{27}$ sino como un salto cualitativo hacia un Estado Constitucional Democrático, superando el argumento contramayoritario planteado en contra de la "judicial review" en su momento por parte de Bickel. ${ }^{28}$

La comunidad jurídica debe evaluar críticamente la corrección de la interpretación constitucional hecha en las sentencias constitucionales, la que se encontrará en las razones y el mérito de los argumentos empleados. A la jurisdicción constitucional debemos exigirle, como intérprete supremo de la Carta Fundamental, que ofrezca sus mejores argumentos al fundar las sentencias.

Como señalara Dworkin, “...la comunidad jurídica debe evaluar a los jueces con criterios intelectuales. Insistiremos que elaboren los mejores argumentos que les sean posibles, y luego nos preguntaremos si sus argumentos son lo suficientemente buenos. Por supuesto, no hay fórmula que garantice que los jueces no serán influidos por los malos argumentos [...]. Todo lo que podemos hacer ante esas malas decisiones es señalar cómo y dónde los argumentos eran malos o las convicciones inaceptables". ${ }^{29}$

\subsection{Análisis de la argumentación jurídica del fallo del Tribunal Constitucional.}

La preocupación central del fallo del Tribunal Constitucional es que el legislador orgánico constitucional, a través del proyecto adecuatorio de LOC del Tribunal Constitucional no restrinja o limite "las facultades de esta Magistratura más allá de lo que establece la Constitución”, bajo pretexto de regular el funcionamiento o los procedimientos del Tribunal, cercenando las funciones atribuidas por la Carta Fundamental, como el mismo Tribunal determina en su considerando $40^{\circ}$.

3.2.1. Las competencias del Tribunal Constitucional están expresa y taxativamente fijadas por la Constitución.

27 Sobre la materia, consultar: Habermas, J. 1998. Facticidad y validez. Sobre el derecho y el Estado democrático de derecho en términos de teoría del discurso. Ed. Trotta, Madrid. Ferreres Comella, V. 1997. Jurisdicción constitucional y democracia. Ed. Centro de Estudios Constitucionales, Madrid, pp. 17-52.

28 Bickel, A. 1962. The least Dangerous Branch: The Supreme Court at the Bar of Politics. Yale University Press, pp. 16-17. Ver asimismo, Elster J. y Slangstad, R. (Coords.) 1988. Constitutionalism and Democracy. Studies in rationality and Social Change., Cambridge University Press, Cambridge, New York, Melbourne, Sydney. Gargarella, R. 1996. La justicia frente al gobierno. Sobre el carácter contramayoritario del poder judicial. Ed. Ariel, Barcelona.

29 Dworkin, R. 1994. El dominio de la vida, Ed. Ariel, Barcelona, pp. 191-192. 
Lo primero que hay que determinar respecto de este temor de los Magistrados del Tribunal Constitucional antes expresado, son las atribuciones que el texto constitucional otorga al Tribunal Constitucional y si el legislador orgánico constitucional las interpreta y aplica correctamente o incorrectamente.

Al respecto debe tenerse presente el texto mismo de la Carta Fundamental. El texto constituye el punto de referencia obligado, es lo primero a lo que se aproxima el intérprete para encontrar una solución al problema planteado.

Recordemos el artículo $6^{\circ}$ de la Constitución que constituyen bases de la institucionalidad y que irradian todo el texto constitucional, por tanto a todos los órganos constitucionales, que son los principios de supremacía constitucional, por tanto la Carta Fundamental obliga a todos los órganos incluido el Tribunal Constitucional que es un órgano instituido por la Constitución y no un órgano constituyente. Como asimismo, el artículo $7^{\circ}$ en su inciso $1^{\circ}$, determina que, "Los órganos del Estado actúan válidamente previa investidura regular de sus integrantes, dentro de sus competencia y en la forma que prescriba la ley". El inciso $2^{\circ}$ determina que "Ninguna magistratura, ninguna persona o grupo de personas puede atribuirse, ni aún a pretexto de circunstancias extraordinarias, otra autoridad o derechos que los que expresamente se le hayan conferido en virtud de la Constitución o las leyes". Termina el inciso $3^{\circ}$ de la disposición señalando que "Todo acto en contravención a este artículo es nulo y originará las responsabilidades y sanciones que la ley señale”.

El artículo 93 de la Constitución determina que son atribuciones del Tribunal Constitucional:

$N^{\circ}$ 1: "Ejercer el control de constitucionalidad de las leyes que interpreten algún precepto de la Constitución, de las leyes orgánicas constitucionales y de las normas de un tratado que versen sobre materias propias de estas últimas, antes de su promulgación.

$N^{\circ} 3$ : "Resolver las cuestiones sobre constitucionalidad que se susciten durante la tramitación de los proyectos de ley o de reforma constitucional y de los tratados sometidos a la aprobación del Congreso.

N6: "Resolver, por mayoría de sus miembros en ejercicio, la inaplicabilidad de un precepto legal cuya aplicación en cualquier gestión que se siga ante un tribunal ordinario o especial, resulte contrario a la Constitución".

A su vez, la reforma constitucional 2005 incorpora un segundo inciso en el nuevo artículo 54, el que sostiene "La aprobación de un tratado requerirá, en cada Cámara, de los quórum que corresponda, en conformidad al artículo 63, y se someterá, en lo pertinente, a los trámites de una ley".

De la consideración de los diversos artículos considerados por el texto constitucional cabe explicitar, sin ninguna duda, que el constituyente, de acuerdo a elementales 
criterios de léxico gramatical, establece una clara distinción entre los términos y conceptos de tratados internacionales y de leyes.

3.2.2. La diferencia de naturaleza jurídica entre tratados internacionales y preceptos legales o leyes

El propio Tribunal Constitucional asumiendo el razonamiento ya hecho por la doctrina anteriormente determina en sentencia Rol $N^{\circ} 288$ de 24 de junio de 1999, respecto del requerimiento formulado respecto del Acuerdo entre Chile y Argentina sobre límites desde el monte Fitz Roy hasta el Cerro Daudet, que "el tratado y la ley son fuentes del derecho diferentes" agregando en el mismo considerando reflexionando sobre la materia con el viejo articulado anterior a la reforma de 2005: "En tal sentido, $y$ sin entrar a profundizar el tema, pueden mencionarse algunos preceptos que decantan la distinción anotada: el artículo $5^{\circ}$ alude a Constitución y tratados internacionales; el artículo habla de someter la aprobación de los tratados a los trámites de la ley y el artículo 82, $N^{\circ} 2$, en estudio, distingue entre la tramitación de los proyectos de ley y la tramitación de los tratados sometidos a la aprobación del Congreso".

El fallo que sometemos a examen crítico reitera la perspectiva asumida en el precedente antes señalado, precisando en su considerando $42^{\circ}$ que " $[. .$.$] el tratado in-$ ternacional no es propiamente una ley, pues no se somete al mismo procedimiento que ella, sino que se rige, por lo menos en su formación, por las voluntades de dos o más Estados". Agregando en el mismo considerando que "En atención a lo anterior es que la Carta Fundamental precisa que las disposiciones de un tratado no podrán ser derogadas, modificadas o suspendidas sino "en la forma prevista en los propios tratados o de acuerdo a las normas generales de derecho internacional" (artículo 54, $\mathrm{N}^{\circ}$ 1), inciso quinto). Con ello, además, se reconoce la intervención del derecho internacional tanto en la formación como en la derogación de los tratados;".

En efecto, como lo determina la Convención de Viena sobre derecho de los tratados, en su artículo $2^{\circ}$, un tratado es un acto jurídico en que concurren la voluntad de dos o más estados u organismos internacionales, a diferencia de un precepto legal o ley que es la expresión unilateral de la voluntad de los órganos colegisladores de un Estado, como ya expusiéramos oportunamente analizando la reforma de $2005 .^{30}$

Tal perspectiva es asumida por el Tribunal Constitucional con anterioridad a la reforma de 2005, como asimismo es conocida por el constituyente instituido de 2005, el que conoce la Convención de Viena sobre Derecho de los Tratados de 1969, como asimismo, los principios imperativos de buena fe, cumplimiento de las obligaciones

30 Nogueira Alcalá, Humberto. 2007, "Reforma constitucional de 2005 y control de constitucionalidad de tratados internacionales", en Revista Estudios Constitucionales, año $5 \mathrm{~N}^{\circ} 1$, Ed. Centro de Estudios Constitucionales, Universidad de Talca - Librotecnia, Santiago, p. 61. 
internacionales y de no poner obstáculos de derecho interno al cumplimiento de las obligaciones por parte de los Estados Parte, contenidas en los artículos 26, 27 y 31 de dicha Convención, válidamente incorporada al derecho interno y vigente, por tanto obligatoria para todos los órganos estatales, y por ello, determina con claridad meridiana la competencia del Tribunal Constitucional sólo y únicamente para realizar control preventivo de constitucionalidad de tratados en el proceso de su incorporación al derecho interno como lo explicitan las disposiciones del artículo $93 N^{\circ} 1$ y $N^{\circ} 3$ de la Constitución, como asimismo no la establece en el artículo $93 \mathrm{~N}^{\circ} 6$, que se remite al control ex post o reparador únicamente de preceptos legales, que es la misma situación que regula el constituyente en el artículo $93 \mathrm{~N}^{\circ} 7$, al determinar que las acciones de inconstitucionalidad sólo se concretan respecto de un "precepto legal declarado inaplicable conforme al número anterior".

La claridad conceptual del constituyente debe ser asumida por el intérprete, de acuerdo a las reglas lingüísticas y gramaticales de la comunidad. A su vez, el intérprete debe guardar consistencia conceptual, vale decir, la coherencia de los conceptos, atribuyéndole siempre a los mismos conceptos iguales significados. Tratado internacional es de acuerdo a su naturaleza jurídica siempre una norma emanada de dos o más estados u organismos internacionales y tiene su fuente en el derecho internacional. Ley o precepto legal es un acto jurídico unilateral de un Estado a través de sus órganos colegisladores, teniendo su fuente y su validez en el derecho interno del Estado.

Un postulado elemental de interpretación constitucional es el de otorgamiento de máxima eficacia a los enunciados normativos constitucionales, exigiendo al intérprete dirigirse hacia aquellas alternativas que maximicen la eficacia de las normas constitucionales, sin distorsionar su contenido. El intérprete constitucional debe optimizar la eficacia de la distinción entre preceptos tratados internacionales y leyes o preceptos legales que hace la Constitución.

A su vez, otro postulado básico de interpretación constitucional es el del efecto útil de las distinciones de términos y conceptos utilizados por la Constitución.

A su vez, ello implica que todo vocablo, enunciado normativo o concepto constitucional tiene que ser interpretado de acuerdo a un efecto útil. En el supuesto caso que un término o vocablo de una disposición es susceptible de dos sentidos, es preferible entenderla en aquel que le permite tener algún efecto antes que en el sentido con el cual no podría producir ninguno. Ningún término o vocablo constitucional puede considerarse inútil, a todas las normas y vocablos debe otorgárseles un efecto útil y eficaz y debe ser armonizado con los demás preceptos normativos. Toda interpretación que ignore preceptos o vocablos expresamente considerados por la Constitución carece de consistencia lógica, racionalidad y razonabilidad. Nuestro Tribunal Constitucional reiteradamente ha manifestado que "no es dable aceptar en la interpretación de la Constitución ni de la ley que sus autores incorporen en sus textos normas superfluas, reiterativas o innecesarias que lejos de contribuir a la clarificación de sus prescripciones, confundan o tornen oscuro o difícil de comprender lo que para el legisla- 
dor es claro y preciso". ${ }^{31}$ El Tribunal Constitucional ya había señalado anteriormente que "cualquier interpretación que conduzca a anular o privar de eficacia algún precepto de ella" 32 no era aceptable.

La fuerza lógica y argumentativa de los razonamientos precedentes expresados por la doctrina constitucional chilena llevó al constituyente de 2005, a no dejar ninguna duda sobre la diferencia de naturaleza entre tratado internacional y ley o precepto legal, para lo cual enmendó el artículo 50 (actual artículo $54 \mathrm{~N}^{\circ} 1$ ), de la Carta Fundamental, en el sentido de que los tratados se someterán, "en lo pertinente", a los trámites de una ley. Los tratados no son leyes ni preceptos legales para la Constitución, como creyeron e interpretaron las jurisdicciones ordinaria y constitucional bajo el imperio de la Constitución de 1925 y parte de la vigencia de la Constitución de 1980, son normas jurídicas de naturaleza y fuerza jurídica diferente a las leyes, nacidas del derecho internacional y que sólo el Estado regula, únicamente para su incorporación al derecho interno, como determina el actual artículo $54 \mathrm{~N}^{\circ} 1$, los cuales se someten "en lo pertinente" al procedimiento que siguen las leyes en el derecho interno. La Constitución establezcámoslo una vez más, no asimila sino que distingue entre la ley como fuente de derecho interno y el tratado como fuente de derecho internacional que se incorpora al derecho interno sin dejar de ser derecho internacional.

Como si ello no fuere suficiente, el constituyente para impedir que órganos del Estado vulneraren tratados internacionales válidamente incorporados al derecho interno, incorporó un inciso $5^{\circ}$ al artículo $54 \mathrm{~N}^{\circ} 1$ que precisa que "las disposiciones de un tratado no podrán ser derogadas, modificadas o suspendidas sino en la forma prevista en los propios tratados o de acuerdo a las normas generales de derecho internacional".

Con ello, la Constitución reconoce expresamente que los tratados una vez ratificados y vigentes no pueden ser afectados en su validez ni en su eficacia por decisiones unilaterales del Estado. Como sosteníamos ya en el artículo antes citado de 2007: "De acuerdo con esta disposición constitucional el Estado chileno no deja ninguna duda sobre la voluntad de hacer efectivas las obligaciones de ius cogens de cumplir de buena fe las obligaciones internacionales contenidas en los artículos 26 y 27 de la Convención de Viena sobre Derecho de los Tratados (principios Pacta Sunt Servanda y Bonna Fide), como asimismo la obligación de no oponer obstáculos de derecho interno al cumplimiento de las obligaciones internacionales voluntaria y libremente aceptadas, generando responsabilidad internacional por ello".

Para contrastar si esta es la determinación del constituyente en 2005, baste establecer los siguientes antecedentes durante la tramitación de la reforma constitucional:

31 Sentencia del Tribunal Constitucional chileno, Rol N ${ }^{\circ} 325$ de 26 de junio de 2001, considerando 47.

32 Sentencia del Tribunal Constitucional chileno, Rol $^{\circ} 33$, de veinte de agosto de mil novecientos ochenta y cinco, considerando 19. 
Como citan los ministros del Tribunal Constitucional disidentes del fallo, en su considerando consignado en el literal p), la Ministra de Relaciones Exteriores, señora Soledad Alvear, en la tramitación del proyecto de reforma constitucional en el Senado en su primer trámite constitucional, precisó:

"El texto de la Constitución regula el proceso de celebración de un tratado internacional, estableciendo las competencias de los distintos órganos del Estado en esta materia (fundamentalmente, del Presidente de la República y el Congreso Nacional), pero nada dice respecto de la derogación o modificación de un tratado, lo que ha suscitado algunos problemas de interpretación, especialmente respecto a la relación entre éstos y las leyes posteriores que se pudieren promulgar $y$ que fueren incompatibles con dichos tratados.

Parece necesario, dijo, regular estos aspectos puesto que se requiere resolver claramente el problema de la primacía de los tratados internacionales en relación con las normas legales del Estado, evitando que una ley posterior pueda derogar o modificar un tratado existente.

Señaló que este tema debería resolverse haciendo consistente la solución de un conflicto entre normas internacionales e internas, dando primacía a las primeras, como lo establece el Derecho Internacional (artículo 27 de la Convención de Viena sobre Derecho de los Tratados), evitando, además, que el Estado incurra en permanentes e, incluso, a veces involuntarias situaciones generadoras de responsabilidad internacional" (Senado de la República. Informe de la Comisión de Constitución, Legislación, Justicia y Reglamento, 6 de noviembre de 2001, pp. 332-333).

Así lo sustuvo también el Supremo Gobierno de la Nación, a través de Ministerio Secretaría General de la Presidencia en el debate sostenido a propósito del segundo Informe de la Comisión de Constitución, Legislación y Justicia del Senado, sobre el artículo 47 b) del proyecto de Ley Orgánica Constitucional del Tribunal Constitucional. Como señala el señor Subsecretario de dicha Cartera, Edgardo Riveros:

"En esa oportunidad, la decisión política del constituyente fue instalar el control preventivo de constitucionalidad sobre determinados instrumentos internacionales que en adelante sometiera el Presidente de la República a la aprobación del Congreso Nacional. No se pretendió dar a la reforma un efecto retroactivo ni general, porque los efectos de las sentencias dictadas por el Tribunal Constitucional en las cuestiones de inaplicabilidad e inconstitucionalidad podrían dejar sin aplicación las disposiciones de un tratado para uno o más casos determinados, en una primera etapa, y las derogarían, en la siguiente.

Es evidente que esos efectos son incompatibles con el Derecho de los Tratados, establecido en la Convención de Viena de 1969, puesta en vigor en nuestro país mediante el decreto $N^{\circ} 381$, del Ministerio de Relaciones Exteriores, de 1981. Lo anterior cobra mayor relevancia si se tiene en consideración que nuestro país, al ratificar dicha Convención, hizo una reserva declarando su adhesión al principio general de inmutabilidad de los tratados. 
Una sentencia del Tribunal Constitucional chileno que deje sin efecto un tratado internacional entraría en franca colisión con el artículo 27 de la Convención de Viena recién citada, según el cual una parte no podrá invocar las disposiciones de su derecho interno como justificación del incumplimiento de un tratado.

En consecuencia, este artículo 47 B, y la indicación que plantea su supresión, deben ser examinados adoptando una óptica coherente con las relaciones internacionales de Chile".

A su vez, el Director Jurídico del Ministerio de Relaciones Exteriores, señor Claudio Troncoso, expresó:

"la modificación que hizo la ley $\mathrm{N}^{\circ} 20.050$ en el número 1) del artículo 50 de la Constitución Política de la República, que pasó a ser artículo 54, descarta absolutamente la interpretación según la cual, hasta entonces, se había asimilado la naturaleza jurídica de los tratados a la de la ley.

Es así que esa conclusión exegética, acuñada por la Corte Suprema sobre la base de la frase que señalaba que la aprobación por el Congreso de los tratados internacionales se sometería a los trámites de una ley, tuvo cabida bajo el imperio de las Constituciones chilenas de 1833, de 1925 e incluso la de 1980, hasta la reforma de 2005. Ella no estaba expresada en un texto normativo explícito.

El claro texto del número 26 del artículo $1^{\circ}$ de la ley $N^{\circ} 20.050$, que sustituyó el artículo 50 de la Constitución, hoy artículo 54, descarta manifiestamente semejante interpretación. El reemplazo que el número 42 del artículo $1^{\circ}$ de la citada ley hizo del artículo 82 de la Carta, hoy artículo 93, apunta en la misma dirección”.

En efecto, aseveró el abogado señor Troncoso, la reforma de 2005 estableció que, de allí en adelante, la aprobación de un tratado se someterá, "en lo pertinente", a los trámites de una ley, lo cual deja meridianamente claro que la Constitución no opera un asimilación entre la naturaleza jurídica de ambos tipos de norma, sino que, reconociendo la especificidad de cada una, hace aplicable a la tramitación legislativa de los proyectos de acuerdo sobre aprobación de tratados las disposiciones sobre formación de las leyes, en lo que sea pertinente, en otros términos, en lo que resulte apropiado.

A mayor abundamiento, recalcó que el párrafo quinto del número 1) del artículo 54 de la Constitución establece que las disposiciones de un tratado sólo podrán ser derogadas, modificadas o suspendidas en la forma prevista en los propios tratados o de acuerdo a las normas generales de derecho internacional. Esto excluye la posibilidad de que esas disposiciones sean suspendidas, para determinados casos, o dejadas sin efecto, en otros, en mérito de una sentencia del Tribunal Constitucional.

Estos razonamientos llevan a la conclusión de que los tratados internacionales se incorporan como tales al ordenamiento jurídico chileno, una vez cumplidas las formalidades del caso, y no como normas de rango o naturaleza legal”. 
Así, una vez que el tratado internacional se encuentra aprobado por el Congreso Nacional y ratificado por el Presidente de la República, genera inmediatamente las obligaciones pertinentes para el Estado si tales tratados están vigentes en el derecho internacional, ellos pasan a ser derecho interno sin dejar de ser derecho internacional, pero, a diferencia de las normas generadas por fuente interna no son susceptibles de derogación, modificación, suspensión, alteración u otras formas de alteración de su aplicación por voluntad unilateral del Estado, teniendo aplicación preferente sobre el derecho interno de acuerdo a lo que el Estado ha consentido libre y voluntariamente. Dicha perspectiva fue expresamente asumida por el gobierno y los diversos sectores representados en el Senado en el primer trámite constitucional de la reforma constitucional de 2005. ${ }^{33}$

Como bien sostienen los ministros disidentes del fallo, en el literal q) de sus considerandos: "Que, como puede apreciarse, el sentido final de la disposición que hoy se contiene en el inciso quinto del artículo 54, $N^{\circ} 1$ ), de la Constitución apuntaba a evitar que Chile incurriera en responsabilidad internacional si hacía primar su normativa interna por sobre un tratado vigente vulnerando las obligaciones derivadas de éste. Ello se concilia perfectamente con lo dispuesto en el artículo 27 de la Convención de Viena sobre el Derecho de los Tratados, de 1969, que preceptúa que: "Una parte no podrá invocar las disposiciones de su derecho interno como justificación del incumplimiento de un tratado (...)", lo que, junto al principio de buena fe o "pacta sunt servanda" en el cumplimiento de tales normas -consagrado en el artículo 26 de la misma Convención-, constituyen la médula de las obligaciones que un Estado contrae al obligarse por un tratado internacional;".

Esta perspectiva es asumida sólo parcialmente por el fallo del Tribunal Constitucional, en su considerando $56^{\circ}$, donde acepta "Que, conforme a las disposiciones constitucionales ya mencionadas, lo que el Estado de Chile no puede hacer es, por ley, derogar las disposiciones de un tratado, pues éste es un acuerdo entre dos Estados, a diferencia de la ley que es una manifestación de la soberanía de un solo Estado".

Cabe comentar esta afirmación hecha por el fallo, ya que es necesario precisar que el Estado de Chile, no puede, ni por ley, ni por modificación constitucional, ni por fallo del Tribunal Constitucional, derogar, modificar o alterar el contenido de un tratado internacional, como lo explicita el artículo $54 \mathrm{~N}^{\circ} 1$, inciso $5^{\circ}$ de la Constitución. Ello se debe a que el tratado tiene su fuente de validez, vigencia y eficacia en el derecho internacional, sin que los estados partes puedan unilateralmente afectarlos. Su validez, aplicabilidad y vigencia sólo pueden ser afectados de acuerdo a los principios y reglas del derecho internacional.

3.2.3. Los tratados internacionales y su misteriosa conversión en precepto legal por el fallo del Tribunal Constitucional, a efectos de crear jurisprudencialmente el control de inaplicabilidad de tratados internacionales y sus consecuencias jurídicas.

33 Segundo Informe de la Comisión de Constitución, Legislación y Justicia del Senado, pp. 188 y ss. 
El Tribunal Constitucional asumiendo el razonamiento desarrollado por la doctrina y hecho operativo por algunos fallos de los tribunales ordinarios de justicia en la década de los años noventa, ya en sentencia Rol $N^{\circ} 288$ de 24 de junio de 1999, respecto del requerimiento formulado respecto del Acuerdo entre Chile y Argentina sobre límites desde el monte Fitz Roy hasta el Cerro Daudet, afirmó que "después de la ratificación formal, el Estado se encuentra obligado a respetar sus cláusulas" (considerando $14^{\circ}$ ), obviamente se refiere a las cláusulas del tratado ratificado.

El Tribunal Constitucional en el fallo comentado entra en una inconsistencia lógica y una falta de coherencia argumental con el fallo antes citado, que ya considerábamos superada, cuando en su considerando $47^{\circ}$ señala que

"El reconocer que un tratado internacional no es lo mismo que una ley no impide que éstos puedan asimilarse y que ambos queden comprendidos en la categoría de "precepto legal". Aquí se concreta una mutación constitucional. Semejante afirmación no tiene apoyo ni el texto de la Constitución, ni en el contexto de la reforma de 2005, como ya hemos analizado. Es una especie de "conejo sacado del sombrero del mago" o un acto de prestidigitación. No le agrega nada al acto de "magia constitucional" del considerando $44^{\circ}$ del fallo, al hacer referencia al Rol $N^{\circ} 346$ del mismo Tribunal, ya que constituye una afirmación propia, sin argumentación jurídica que pueda sostenerse en el texto constitucional, invocando una sentencia propia, anterior a la reforma constitucional de 2005, por tanto, no pertinente a la situación normativa actual del texto constitucional, apartado del sentido y fin de esta última reforma, ya que ella busca inequívocamente impedir la vulneración del derecho internacional y garantizar el pleno respeto a los artículos 26 y 27 de la Convención sobre Derecho de los Tratados, como ya ha sido suficientemente documentada a través de los personeros del Ejecutivo y del Congreso Nacional que actuaron como constituyente instituido o derivado en 2005, en el párrafo anterior de este análisis, contrariamente a lo que sostiene el considerando $46^{\circ}$ del fallo, el cual desconoce el esfuerzo de coherencia y consistencia del constituyente de 2005 , de respeto escrupuloso al principio de buena fe y de cumplimiento de las obligaciones internacionales exigido por el artículo 26 de la Convención de Viena sobre Derecho de los Tratados, como del artículo 27 de ella, que impide al Estado Parte generar obstáculos de derecho interno al cumplimiento de las obligaciones internacionales. Todo ello respetando y garantizando el honor del Estado chileno que se vería vulnerado generando responsabilidad internacional, si se incumplieran los tratados internacionales válidos y vigentes, respecto de los cuales el estado chileno ha reconocido intangibilidad mientras ellos sean válidos, vigentes y eficaces, al ratificar la Convención analizada. Por ello puede sostenerse que la reforma de 2005 sí agrega mucho contenido a la Carta Fundamental en materia de respeto de los tratados internacionales.

Si un tratado se establece en base a los modos de producción normativa del derecho internacional que determina su validez, vigencia y eficacia, siendo expresión de la voluntad de dos o más estados u organismos internacionales, no se ve en base a qué argumento jurídico pueda el Tribunal Constitucional señalar que este tratado es equiva- 
lente a un precepto legal, ya que este último se establece de acuerdo a los modos de producción normativa determinada por la Constitución, la que determina su validez, vigencia y eficacia, siendo expresión de los órganos colegisladores del Estado chileno. Como son enunciados normativos de órdenes jurídicos diferentes, ninguno puede invalidar al otro o restarle fuerza normativa en sus respectivos planos. Los enunciados normativos de rango legal ceden necesariamente frente a la fuerza aplicativa preferente de los tratados en caso de contradicción o colisión entre ambos, en virtud de la obligación del Estado chileno de cumplir sus obligaciones internacionales de buena fe y de no poner obstáculos de derecho interno al cumplimento de ellas, además de respetar y garantizar los actos propios libre y voluntariamente expresados en la ratificación del tratado, lo que es exigido por principios imperativos de derecho internacional.

Por otra parte, el fallo recurre a la opinión aislada del Senador Larraín a la que se hace referencia como carta de apoyo a sus consideraciones, lo que solo confirma un vicio al cual se acude en varias oportunidades que es la de citar opiniones aisladas que no constituyen acuerdos de los órganos que participan del proceso constituyente derivado, y que por tanto, valen como cualquier otra opinión aislada de parlamentarios que participaron en el debate de la reforma de 2005, no siendo historia fidedigna del precepto constitucional respectivo, para quienes gustan del originalismo.

El Tribunal Constitucional en el fallo analizado comete un error grave de derecho al considerar que solo el legislador no puede afectar el contenido de un tratado válido y vigente, incorporado al derecho interno. Tampoco el Tribunal Constitucional ni ningún otro órgano del Estado puede alterar la validez, vigencia y eficacia de un tratado válidamente incorporado al orden jurídico nacional en forma unilateral, recordemos una vez más el texto de la Constitución, el cual nos precisa que sólo el Presidente de la República, tiene "la facultad exclusiva para denunciar un tratado o retirarse de él" como señala el inciso sexto del artículo $54 \mathrm{~N}^{\circ} 1$, siempre que actúe "en la forma prevista en los propios tratados o de acuerdo a las normas generales del derecho internacional", como determina imperativamente el artículo $54 \mathrm{~N}^{\circ} 1$, inciso $5^{\circ}$.

Todo acto de cualquier órgano estatal, incluido el Tribunal Constitucional, que altere la validez, vigencia, aplicación y eficacia de un tratado internacional válidamente incorporado al derecho interno genera responsabilidad internacional. La responsabilidad internacional del Estado se concreta por la acción u omisión contraria al derecho internacional que lo obliga, realizada por cualquier órgano estatal, incluido el Tribunal Constitucional o la Corte Suprema de Justicia, como bien ya lo determinó la Corte Interamericana de Derechos Humanos en el "caso La última tentación de Cristo", ${ }^{34}$ como lo recuerda el voto disidente de varios magistrados del Tribunal, en su considerando referenciado con el literal $r$ ), en lo cual el voto de los ministros disidentes es claro: "Tal argumento, propio exclusivamente de un análisis de derecho interno, resulta desvirtuado si se tiene presente que la responsabilidad internacional por la comi-

34 Corte Interamericana de Derechos Humanos, Caso La última tentación de Cristo, sentencia de 5 de febrero de 2001 , serie $C \mathrm{~N}^{\circ} 73$. 
sión de un ilícito internacional es atribuible al Estado como sujeto de derecho internacional y no a órganos determinados de éste, como podría ser el caso del Congreso Nacional o de los tribunales de justicia considerados independientemente".

A ello debe agregarse la necesaria toma de conciencia de los tribunales nacionales sobre el obligatorio "control de convencionalidad" que deben hacer todos los tribunales nacionales, el cual posibilita solo a aplicar las leyes internas cuando no estén en contravención con los tratados internacionales, especialmente los tratados de derechos humanos, como precisó la Corte Interamericana de Derechos Humanos en el "caso Almonacid Arellano y otros con Chile", lo que vale la pena recordar:

"124. La Corte es consciente que los jueces y tribunales internos están sujetos al imperio de la ley y, por ello, están obligados a aplicar las disposiciones vigentes en el ordenamiento jurídico. Pero cuando un Estado ha ratificado un tratado internacional como la Convención Americana, sus jueces, como parte del aparato del Estado, también están sometidos a ella, lo que les obliga a velar porque los efectos de las disposiciones de la Convención no se vean mermadas por la aplicación de leyes contrarias a su objeto y fin, y que desde un inicio carecen de efectos jurídicos. En otras palabras, el Poder Judicial debe ejercer una especie de "control de convencionalidad" entre las normas jurídicas internas que aplican en los casos concretos y la Convención Americana sobre Derechos Humanos. En esta tarea, el Poder Judicial debe tener en cuenta no solamente el tratado, sino también la interpretación que del mismo ha hecho la Corte Interamericana, intérprete última de la Convención Americana". ${ }^{35}$

Es en virtud de este error de derecho con la consiguiente consecuencia de responsabilidad internacional del Estado, que el fallo del Tribunal considera inocente o sin consecuencias jurídicas afirmar la tesis de un sentido amplio del vocablo "precepto legal", como precisa en su considerando $48^{\circ}$, "que incluye a los tratados internacionales", lo que constituye una perspectiva incoherente con el texto de la Carta Fundamental, sin lógica y sin apoyo en el mismo, en contradicción con las precisiones introducidas en la materia por la reforma de 2005 como ya hemos argumentado y probado, como asimismo con un desconocimiento de la fuerza normativa del texto constitucional que establece las atribuciones específicas en materia de control de constitucionalidad de tratados en los artículos $93 \mathrm{~N}^{\circ} 1^{\circ}$ y $3^{\circ}$ en forma taxativa. La interpretación conforme a la Constitución tiene su límite en la propia norma, ya que no le está permitido al operador judicial adulterar las palabras ni realizar una interpretación contra norma expresa; como asimismo en vulneración del principio de efecto útil de las distinciones de vocablos y conceptos constitucionales, lo que lo hace inconsistente con su propia jurisprudencia, ya mencionada sobre este principio, determinando una perspectiva puramente voluntarista y subjetiva de los ministros que forman parte de la mayoría.

35 Corte Interamericana de Derechos Humanos, Caso Almonacid Arellano y otros vs. Chile, de fecha 26 de septiembre de 2006, Serie $C^{\circ} \mathrm{N}^{\circ} 153$, párrafos $\mathrm{N}^{\mathrm{os}} 124-126$. 
De acuerdo a lo argumentado, puede sostenerse claramente que el constituyente consciente y reflexivamente distinguió la naturaleza jurídica, la validez, la aplicabilidad y vigencia de los tratados respecto de las leyes o preceptos legales. Por ello no puede el tribunal constitucional asimilar lo que el constituyente claramente diferenció utilizando vocablos diferentes, los que deben ser entendidos como tales, dándoles su sentido natural y jurídico, de acuerdo a su naturaleza y a su diversa fuerza normativa y aplicativa.

Reflejo de este voluntarismo interpretativo subjetivo es la afirmación que se hace en el considerando $41^{\circ}$ del fallo, “Que respecto de los tratados internacionales, luego de la reforma constitucional aludida, esta Magistratura efectúa dos órdenes de controles. [...]. Segundo, un control ex post y concreto -facultativo- de constitucionalidad de una norma de un tratado que, en cuanto "precepto legal", pueda resultar contraria a la Constitución en su aplicación en "cualquier gestión que se siga ante un tribunal ordinario o especial”, esto es, el Tribunal Constitucional puede declarar inaplicable la disposición de un tratado a un caso concreto, conforme a la atribución que le otorga el $N^{\circ} 6^{\circ}$ del inciso primero del artículo 93 de la Constitución, arriba transcrito. De este modo, tal como lo ha sostenido el profesor y doctor en derecho Teodoro Ribera, "lâ validez del tratado deriva de la legitimidad otorgada por la Constitución y es en ese marco y respetando a aquella que el tratado internacional puede tener vigencia interna" (Informe enviado a la Comisión de Constitución, Legislación, Justicia y Reglamento del Senado, de fecha 9 de diciembre de 2006, p. 7);".

En esta afirmación se equivocan los ministros del Tribunal que conforman la mayoría y el profesor Rivera, ya que elementales conocimientos de derecho permiten saber que un tratado es una norma jurídica que emana del derecho internacional y sus modos de producción normativa, la validez de un tratado está determinada por su gestación de acuerdo al procedimiento determinado por el derecho internacional y no por la Constitución de un Estado, por lo dispuesto en el propio tratado, por la Convención de Viena sobre Derecho de los Tratados de 1969 y por los principios generales del derecho internacional. Además, hay norma positiva expresa introducida por la reforma constitucional de 2005 , en el artículo $54 \mathrm{~N}^{\circ} 1$, inciso $5^{\circ}$, que muestra la falacia de tal afirmación: "Las disposiciones de un tratado solo podrán ser derogadas, modificadas o suspendidas en la forma prevista en los propios tratados o de acuerdo a las normas generales de derecho internacional". Tal afirmación constitucional positiva ahorra cualquier comentario adicional sobre la validez de los tratados.

Cabe explicitar nuevamente que la Constitución sólo regula el procedimiento de incorporación del tratado al derecho interno, pero no su validez, una vez incorporado el tratado de acuerdo al procedimiento previsto por la Carta Fundamental, dicho tratado se convierte en norma vinculante y obligatoria para todos los órganos estatales, todas las personas y grupos, los cuales deben conformar sus actuaciones a las obligaciones y derechos que determina el tratado. Así, una vez que el tratado internacional se encuentra aprobado por el Congreso Nacional y ratificado por el Presidente de la República, genera inmediatamente las obligaciones pertinentes para el Estado si tales tratados están vigentes en el derecho internacional, ellos pasan a ser derecho interno 
sin dejar de ser derecho internacional, pero, a diferencia de las normas generadas por fuente interna no son susceptibles de invalidación, alteración, inaplicación o suspensión por voluntad unilateral del Estado, teniendo aplicación preferente sobre el derecho interno de acuerdo a lo que el Estado ha consentido libre y voluntariamente, aplicándose los ya referidos artículos 26 y 27 de la Convención de Viena sobre Derecho de los Tratados, en lo cual se encuentra comprometida la responsabilidad internacional del Estado por la actuación de cualquiera de sus órganos y está en juego el honor del Estado en el cumplimiento de buena fe de sus obligaciones jurídicas.

Esta posición del fallo del Tribunal Constitucional tiene además importantes implicancias jurídicas y políticas, piénsese en el caso de los tratados que establecen límites fronterizos si pudieran alterarse a voluntad del propio Estado, determinado a través de uno de sus propios órganos como es un Tribunal Constitucional u otro tribunal que ejerza jurisdicción constitucional, el cual el propio Estado contra lo que ha sido su conducta de aprobar y ratificar un tratado, volviera unilateralmente sobre sus pasos (doctrina de los actos propios), determinando su suspensión o inaplicabilidad. Todo el derecho internacional quedaría, de acuerdo con esta peregrina tesis, a merced de los obstáculos que unilateralmente quisiera interponer cada Estado al cumplimiento de sus obligaciones internacionales, afectando la validez, vigencia y eficacia de todas las fuentes del derecho internacional.

En un mundo globalizado, los estados requieren otorgar seguridad jurídica a nacionales y extranjeros, como asimismo adoptar rápidas decisiones económicas, sociales, culturales y políticas, por la celeridad y aprovechamiento de circunstancias del tráfico jurídico y económico social, debiendo lograr un equilibrio adecuado entre ambas exigencias. Ello exige otorgar a los operadores jurídicos y sociales el más alto grado de seguridad jurídica de los derechos e intereses comprometidos a través de tratados internacionales, como asimismo, que este control preventivo sea suficientemente rápido para no entorpecer las decisiones oportunas y eficaces del Estado. No hay seguridad para los operadores internacionales o extranjeros y para los ciudadanos chilenos si las normas pueden ser alteradas con cierta discrecionalidad por vía jurisprudencial, además de la falta de seguridad jurídica del mantenimiento uniforme de criterios por los tribunales superiores de justicia, ello es grave en materia de confianza para las entidades internacionales o extranjeras que desean realizar inversiones en o por parte de otros estados, todos ellos requieren certeza del cumplimiento de las normas internacionales incorporadas válidamente al derecho interno y la seguridad de que ellas dejarán de aplicarse sólo de acuerdo con el sistema de denuncias, retiro o término de los Tratados o Pactos determinado por la Convención de Viena sobre Derecho de los Tratados, las normas determinadas en la Convención o tratado específico, o de acuerdo a los principios generales del Derecho Internacional.

De una interpretación sistemática y finalista del conjunto de este artículo $54 \mathrm{~N}^{\circ} 1$ y artículo $93 \mathrm{~N}^{\text {s }} 1$ y 3 de la Constitución se desprende claramente, y no podría ser de otra manera, la voluntad del constituyente de respetar integralmente los principios y reglas del derecho internacional, evitando toda especie de esquizofrenia jurídica, enfermedad grave del Estado que genera responsabilidad internacional. 
El derecho convencional internacional válidamente celebrado e incorporado al derecho chileno, de acuerdo al procedimiento determinado constitucionalmente, tiene aplicabilidad preferente frente a las normas de derecho interno, mientras no pierda validez, vigencia y eficacia de acuerdo al derecho internacional, como lo explicita expresamente el artículo $54 \mathrm{~N}^{\circ} 1$, incisos 5 y 6 de la Constitución.

Este voluntarismo interpretativo del fallo, sin apoyo en el derecho constitucional positivo, además llega a sostener en el considerando $43^{\circ}$, que "Que, respecto a la jerarquía de los tratados internacionales, luego de la reforma constitucional de 2005 a que ya se ha hecho referencia, y no obstante haberse precisado y aclarado con la modificación de la frase final del inciso primero del $\mathrm{N}^{\circ} 1$ del artículo 54 de la Constitución ("...se someterá, en lo pertinente, a los trámites de una ley") que aquéllos no son propiamente una ley, como ya lo había por cierto entendido esta Magistratura (Rol $N^{\circ} 288$ ), ello no es óbice a que, en cuanto a su rango, este Tribunal ha estimado que deben sujetarse a la Carta Fundamental;". Esta afirmación que constituye un pre-juicio sin sustento constitucional y sobre la cual no hay un razonamiento jurídico que se apoye en el texto constitucional, sino un mero recurso a una propia afirmación anterior, también sin argumentación basada en texto constitucional, de que en la sentencia Rol $N^{\circ} 346$, esta Magistratura dejó claramente establecido que la Carta Fundamental "autoriza el control de constitucionalidad de determinados preceptos legales, entre los que deben considerarse los tratados internacionales"; lo que constituye una afirmación tautológica.

En el considerando 49, el fallo intenta esbozar un apoyo para posibilitar un fundamento para el control reparador de constitucionalidad, afirmando "Pues bien, si se requirió reformar la Constitución para poder suscribir un tratado que podía pugnar con ella, es evidente que un tratado internacional tiene rango inferior a ella, rango de ley, y sus preceptos son preceptos legales perfectamente susceptibles de ser requeridos de inaplicabilidad, en la medida que se cumplan los demás requisitos que la Constitución establece para ello;".

Las afirmaciones sostenidas en el considerando citado precedentemente es una nueva petición de principio sin fundamento constitucional, como asimismo un salto lógico, el hecho de que un tratado que pugne con la Constitución, requiera una modificación constitucional para incorporarse al derecho interno, o como ocurre en otros países, se pueda incorporar aprobándolo con el quórum correspondiente a la reforma constitucional, sólo indica que la incorporación del tratado al derecho interno debe respetar los principios y reglas constitucionales, por lo cual existe el control preventivo de constitucionalidad previsto expresamente en el artículo $93 \mathrm{~N}^{\mathrm{os}} 1$ y 3 de la Constitución, el cual es un punto pacífico y sin discusión. Pero ello nada dice sobre la equivalencia de fuerza normativa de un tratado válidamente incorporado al derecho interno en relación a la ley, este es el salto lógico no fundado que realizan los ministros en su argumentación si un tratado tiene rango inferior a la Constitución, sólo imaginan que puede tener fuerza de ley, si un tratado no es una ley ni tiene naturaleza de ley, como el mismo fallo ha debido reconocer, donde está la coherencia argumen- 
tativa para afirmar luego que tiene fuerza de ley. Los ministros de mayoría en este fallo olvidan que el derecho positivo válido y vigente contenido en la Convención de Viena sobre Derecho de los Tratados, impide que sea considerado un tratado como equivalente a normas de derecho interno, ya que el tratado tiene una especial fuerza activa y pasiva, especialmente respecto de la ley, ya que tiene una aplicación preferente frente a esta última, sea que ella se haya incorporado antes o después del tratado al ordenamiento jurídico, ya que si tuviera la misma fuerza normativa, una ley posterior podría aplicarse contra un tratado anteriormente incorporado al derecho interno, si se actuara de dicha manera, se estaría incurriendo claramente en responsabilidad internacional, se vulneraría el artículo 27 de la Convención de Viena que impide poner obstáculos de derecho interno al cumplimiento de los tratados, no debe olvidarse que la Convención citada, sin dejar de ser derecho internacional es también derecho interno válido y vigente, obligatorio para todos los órganos instituidos, incluido el Tribunal Constitucional, el cual debe ejercer sus competencias sin desconocerla, ya que de lo contrario estaría fallando en vulneración de las fuentes del derecho vigente, que se presume conocido (iura novit curia), lo cual constituiría una sentencia arbitraria e írrita, que vulnera los principios básicos del debido proceso. Recordemos solamente en la materia, lo señalado por la Corte Interamericana, en el caso Almonacid Arellano contra Chile: "125. En esta misma línea de ideas, esta Corte ha establecido que "[s]egún el derecho internacional las obligaciones que éste impone deben ser cumplidas de buena fe y no puede invocarse para su incumplimiento el derecho interno". Esta regla ha sido codificada en el artículo 27 de la Convención de Viena sobre el Derecho de los Tratados de $1969 "{ }^{36}$ Todo ello muestra la falacia de la argumentación de los ministros de la mayoría en este considerando. Además, los Ministros de mayoría del Tribunal Constitucional en este fallo, olvidan la propia jurisprudencia del Tribunal Constitucional, que establece el deber del intérprete de "hacer todos los esfuerzos dentro de lo permitido por la Ley Suprema, para encontrar una interpretación conciliatoria entre las normas de un tratado y los preceptos de la Constitución". ${ }^{37}$

Si la Constitución hubiere asimilado los tratados a las leyes o preceptos legales y les hubiere dado la misma fuerza normativa, no habría distinguido entre tratados internacionales y leyes en el artículo $93 \mathrm{~N}^{\mathrm{os}} 1^{\circ}$ y $3^{\circ}$ de la Constitución, ya que ello tendría un efecto absolutamente inútil, lo que no es predicable de la Constitución, como reiteradamente lo ha sostenido la misma jurisprudencia del Tribunal Constitucional y reconocen los ministros del tribunal que conforman el voto de minoría. El texto de dichos numerales del artículo 93 se habría referido sólo a preceptos legales o con fuerza de ley, si fuese razonable, consistente y coherente la argumentación del fallo en análisis.

Dicha perspectiva tampoco es la seguida por la jurisprudencia de la Excma. Corte Suprema de Justicia en fallos bastante uniformes desde 1995, los cuales reconocen la

36 Sentencia de la Corte Interamericana de Derechos Humanos, Caso Almonacid Arellano y otros vs. Chile, Serie $\mathrm{CN}^{\circ} 153$, de fecha 26 de septiembre de 2006, párrafos 123-125.

37 Sentencia del Tribunal Constitucional chileno, rol $\mathrm{N}^{\circ} 309$, de 4 de agosto de 2000 , considerando $3^{\circ}$, en examen de la constitucionalidad del Convenio 169 de la OIT. 
aplicabilidad preferente de los tratados sobre las leyes. ${ }^{38}$ Citemos algunos párrafos pertinentes de sentencias de la Corte Suprema de Justicia de la década de los noventa. La Corte Suprema de Justicia, en fallo de fecha 26 de octubre de 1995, ha afirmado que la prescindencia de aplicación de normas de derechos humanos contenidas en tratados internacionales compromete la seguridad y honor del Estado de Chile y debilita el Estado de Derecho, no pudiendo invocarse el derecho interno para incumplir obligaciones internacionales:

"Que se comprometería la seguridad y honor del Estado de Chile ante la comunidad internacional, como se destaca en la sentencia recurrida, si este Tribunal efectivamente prescindiera de aplicar las normas internacionales cuando ello fuera procedente. Pues, es un principio reconocido universalmente que las naciones civilizadas no pueden invocar su derecho interno para eludir las obligaciones y compromisos internacionales asumidos por dichos tratados, lo que, ciertamente, de producirse debilitaría el Estado de Derecho". ${ }^{39}$

La Corte Suprema de Justicia, en sentencia Rol $N^{\circ} 469-98$, de fecha 9 de septiembre de 1998, reconocido que los tratados deben cumplirse de buena fe:

“...El Estado de Chile se impuso en los citados convenios internacionales la obligación de garantizar la seguridad de las personas (...), quedando vedado por este Convenio disponer medidas que tendieren a amparar los agravios cometidos contra personas determinadas o lograr la impunidad de sus autores, teniendo especialmente presente que los acuerdos internacionales deben cumplirse de buena fe".

Los ministros que concurren en mayoría a este fallo, intentan otra línea de argumentación para afirmar la igual fuerza de ley de los tratados internacionales, sosteniendo en el considerando $54^{\circ}$ "Que, de otro modo, no se explicaría cómo el constituyente de 2005 estableció el control preventivo y obligatorio de constitucionalidad "de las normas de un tratado que versen sobre materias propias de estas últimas" (artículo 93, inciso primero, $N^{\circ} 1^{\circ}$, de la Constitución), haciendo referencia directa a las leyes orgánicas constitucionales. A ello debe agregarse el control preventivo y facultativo de constitucionalidad de los tratados internacionales, en conformidad al artículo 93, inciso primero, $N^{\circ} 3^{\circ}$, de la Constitución, que también supone que el tratado pueda contener disposiciones propias de ley"; agregando en el considerando $55^{\circ}$ que "Que si el tratado no es una ley en sentido estricto, pero puede contener disposiciones propias de ley, tales disposiciones serán sin lugar a dudas "preceptos legales", que pueden perfectamente ser objeto de un requerimiento de inaplicabilidad por inconstitucionalidad. La solución contraria, esto es, la que deja al margen del requerimiento

38 Por todos, Sentencia de Excma. Corte Suprema de 26 de octubre de 1995, confirmando sentencia de I. Corte de Apelaciones de Santiago, Rol N ${ }^{\circ} 24.344$ de fecha 22 de diciembre de 1994, Revista Gaceta Jurídica $\mathrm{N}^{\circ} 177$, pp. 165 y siguientes. Sentencia de la Excma. Corte Suprema de Justicia, Rol $\mathrm{N}^{\circ} 5.556$, de 26 de octubre de 1996. Revista Gaceta Jurídica $N^{\circ} 185$, p. 120.

39 Sentencia de la Corte Suprema de Justicia, fecha 26 de octubre de 1995, considerando $14^{\circ}$. 
de inaplicabilidad a los preceptos de un tratado internacional, según se declarará, es contraria a la Constitución;".

El constituyente al establecer el artículo $93 \mathrm{~N}^{\circ} 1$ de la Constitución que un tratado que se refiera a materias que en el derecho interno son propias de Ley Orgánica Constitucional pase por un control preventivo obligatorio de constitucionalidad sólo está siendo coherente con el principio de que determinadas materias deben ser aprobadas en el Congreso Nacional con determinado quórum, sea a través de tratados o a través de leyes. Es obvio como por lo demás el propio Tribunal Constitucional ha actuado, que si un tratado contiene normas que implican transferencia de competencias constitucionales a órganos internacionales o supranacionales ha exigido previa reforma constitucional, lo que no equivale a que la norma del tratado sea Constitución en términos formales, porque en tal argumentación deberíamos sostener que el Tratado de Roma que regula la Corte Penal Internacional es Constitución. Ello muestra nuevamente lo erróneo de la afirmación del fallo del Tribunal Constitucional en el considerando analizado. Como asimismo muestra la falacia argumentativa del considerando $55^{\circ}$. El tratado es siempre tratado y tiene fuerza jurídica de tratado, diferente de la fuerza jurídica de las leyes, por ello la Constitución distingue expresamente el control de constitucionalidad de preceptos legales o leyes y de tratados internacionales.

Los ministros que conforman la mayoría en este fallo, en el considerando $58^{\circ}$ de la sentencia, reconocen expresamente "Que, en efecto, una declaración de inconstitucionalidad de un precepto de un tratado internacional por parte de este Tribunal implicaría una vulneración a las normas del derecho internacional sobre formación y extinción de los tratados, así como una infracción a las disposiciones de la Constitución Política que otorgan al Presidente de la República la conducción de las relaciones internacionales y la negociación, conclusión y ratificación de tratados internacionales (artículos 54, $N^{\circ} 1^{\circ}$, y 32, $N^{\circ} 15^{\circ}$, de la Constitución), pues esa declaración de inconstitucionalidad genera el mismo efecto que una ley derogatoria: expulsar al precepto legal del ordenamiento jurídico".

Sin embargo, en el mismo considerando $58^{\circ}$, los ministros que conforman la mayoría insisten en que "Esta situación es diferente a la del requerimiento de inaplicabilidad, en que la norma jurídica sigue vigente, sólo que es inaplicable a una gestión judicial determinada". A ello agregan en el considerando $60^{\circ}$, "Que, de esta manera, la declaración de inaplicabilidad es una forma de control concreto de constitucionalidad, diferente al carácter abstracto que se sostiene tenía el que se ejercía a través de esta acción con anterioridad a dicha modificación constitucional. En tal sentido, este Tribunal (Rol $N^{\circ}$ 546) ha señalado que "De la simple comparación del texto de la norma(...) con el antiguo artículo 80 de la Carta Fundamental (...)se desprende que(...) mientras antes se trataba de una confrontación directa entre la norma legal y la disposición constitucional, ahora se está en presencia de una situación diferente, por cuanto lo que podrá (ser) declarado inconstitucional es la aplicación del precepto legal impugnado, lo que relativiza el examen abstracto de constitucionalidad, marcando una clara diferencia con el texto constitucional anterior". Agregando en el considerando 
$61^{\circ}$ "Que lo anteriormente descrito es de la esencia del ejercicio de la función jurisdiccional que le corresponde a esta Magistratura en conformidad con lo que establece el $N^{\circ} 6^{\circ}$ del inciso primero del artículo 93 de la Ley Suprema y no guarda relación con lo establecido en el inciso quinto del $N^{\circ} 1^{\circ}$ del artículo 54 de la Carta Fundamental, que se refiere a las atribuciones propias del Poder Legislativo".

La modalidad de control de constitucionalidad consignada en el artículo 93, inciso 1, $N^{\circ} 6$ de la Constitución, que como señala el fallo, es un control de inaplicabilidad sobre preceptos legales, es un control concreto con efecto inter partes, por lo que no se cuestiona el enunciado normativo en cuanto tal, sino la norma que emana de su aplicación al caso concreto. Sin embargo esta modalidad de control de constitucionalidad sobre preceptos legales en control reparador no agrega nada a la falta de competencia y jurisdicción del Tribunal Constitucional para el control reparador de tratados internacionales, que no existe en el texto constitucional y que la argumentación de la mayoría que conforma el fallo no logra consistencia y coherencia con el texto expreso de la Carta Fundamental, constituyendo una mera especulación reflexiva sin fundamento plausible. Es obvio además que el artículo 93 , inciso $1^{\circ}, \mathrm{N}^{\circ} 6$, no tiene relación con el artículo 54 , $\mathrm{N}^{\circ} 1$, inciso $5^{\circ}$, ya que se refieren a normas jurídicas que provienen de dos ordenamientos diferentes, los tratados con fundamento, validez y eficacia en el derecho internacional, los que no pueden ser afectados por el Estado Parte, que es lo que expresa dicha disposición, la que no se aplica en nada a la competencia del Tribunal Constitucional referente al artículo $93 \mathrm{~N}^{\circ} 6$ que se refiere al control reparador de inaplicabilidad de preceptos legales que tienen su fuente de validez y eficacia en el derecho interno, sin conexión alguna con el artículo $54 \mathrm{~N}^{\circ} 1$, inciso quinto. La coherencia, consistencia y armonía del texto constitucional en la materia es perfecta. Nada de lo afirmado permite sostener que la Constitución afirma, contra texto expreso del artículo 93, una competencia implícita del Tribunal Constitucional para realizar control reparador de constitucionalidad de tratados a través del control de inaplicabilidad expresamente previsto únicamente para preceptos legales. Recordemos el principio básico de nuestro sistema constitucional como Estado de derecho y estado constitucional contenido en el inciso $2^{\circ}$ del artículo $7^{\circ}$ del capítulo $1^{\circ}$ de la Constitución, el cual irradia toda la Constitución incluido el capítulo del Tribunal Constitucional y sus atribuciones, el que determina, repitámoslo una vez más, que "Ninguna magistratura, ninguna persona ni grupo de personas puede atribuirse, ni aún a pretexto de circunstancias extraordinarias, otra autoridad o derechos que los que expresamente se les haya conferido en virtud de la Constitución o las leyes", agregando el inciso $3^{\circ}$ : "Todo acto en contravención a este artículo es nulo y originará las responsabilidades y sanciones que la ley señale".

Es claro que la Constitución de 1980 en su texto original fortaleció las competencias del Tribunal Constitucional en relación a la Constitución de 1925, reformada en 1971 , las que luego han sido reforzadas por la reforma constitucional de 2005, como explicita el considerando $63^{\circ}$ de la sentencia, pero no estableció el control reparador de constitucionalidad de tratados internacionales por respeto al derecho internacional, además es una inexactitud importante señalar como lo hace el considerando $64^{\circ}$, que la voluntad constituyente de fortalecer y concentrar el control normativo de cons- 
titucionalidad en el Tribunal Constitucional, "no se concilia con dicho propósito el concluir que la modificación constitucional antes mencionada eliminó el control de constitucionalidad a posteriori de los tratados internacionales que se ejerce a través de la declaración de inaplicabilidad por inconstitucionalidad", ya que el control a posteriori de tratados no ha sido eliminada de la Constitución, ya que nunca ha estado establecido, lo que se eliminó fue la interpretación pretoriana de los órganos jurisdiccionales por vía jurisprudencial, lo que es muy distinto. Por lo demás el constituyente tiene el legítimo derecho de eliminar eventuales líneas jurisprudenciales que sean nocivas de la inserción de Chile en el concierto internacional como un Estado respetuoso de sus compromisos internacionales y que honra su palabra libre y voluntariamente comprometida a través de los tratados internacionales debidamente ratificados.

Por otra parte, no es sostenible de acuerdo con los artículos 26 y 27 de la Convención sobre derecho de los tratados, que establece el principio imperativo de cumplimiento de buena fe de las obligaciones internacionales, como el de no poner obstáculos de derecho interno al cumplimiento de tales obligaciones, la perspectiva insinuada en el considerando $65^{\circ}$ de la sentencia, de que "es necesario reiterar que la atribución comprendida en el artículo 93, inciso primero, $N^{\circ} 6^{\circ}$, de la Carta Fundamental, difiere notoriamente de aquella contenida en el $N^{\circ} 7^{\circ}$ del mismo precepto constitucional, no obstante la relación existente entre ambas. En el caso de esta última, esta Magistratura expulsa del ordenamiento jurídico un precepto legal con efecto "erga omnes" y sin alcance retroactivo. Sin embargo, no le corresponde hacerlo respecto de una disposición de un tratado internacional, puesto que ello implicaría una infracción a las normas del derecho internacional sobre formación y extinción de los tratados, así como a las disposiciones de la Constitución Política que otorgan al Presidente de la República la conducción de las relaciones internacionales y la negociación, conclusión y ratificación de tratados internacionales (artículos $54, N^{\circ} 1^{\circ}, y 32, N^{\circ} 15^{\circ}$, de la Constitución). Ello, en atención a que la declaración de inconstitucionalidad contemplada en el artículo 93, inciso primero, $N^{\circ} 7^{\circ}$, de la Ley Suprema genera el mismo efecto que una ley derogatoria: elimina el precepto legal del ordenamiento jurídico. Esta situación es diferente a la del requerimiento de inaplicabilidad, en que la norma sigue vigente, sólo que es inaplicable a una gestión judicial determinada;" lo cual ya había sido expresado en el considerando $42^{\circ}$, donde se sostiene: "En cambio, en el caso de la declaración de inaplicabilidad de una norma de un tratado ya promulgado y vigente, dicha declaración sólo producirá un efecto particular en el orden interno y para el caso concreto que constituye la gestión pendiente en que la norma no se podrá aplicar, sin que se altere de este modo la generalidad de la disposición del tratado ni su vigencia desde el punto de vista del derecho internacional, cuestión que conforme se verá, según se desarrolla en esta sentencia, es de la máxima importancia”.

En efecto, tal como lo precisan los cuatro ministros del Tribunal Constitucional disidentes del fallo en esta materia, en sus respectivos votos, los Ministros Cea, Colombo y Peña, precisan en el literal v) de sus fundamentos que si se "detiene o paraliza temporalmente" (aunque sea para un caso concreto) la aplicación de una norma de un tratado internacional, ello importa una suspensión del mismo con clara trasgresión del 
artículo 54, $N^{\circ} 1$ ), inciso quinto, de la Carta Fundamental. Ello, debido a que la referida suspensión opera en forma diferente a lo previsto en el tratado o a las normas generales de derecho internacional", agregando en el fundamento de su voto en el literal w), "Que, sobre la base de lo afirmado, no puede declararse la inaplicabilidad de una norma contenida en un tratado internacional vigente, pues ello importaría una suspensión de la misma y una vulneración del artículo 54, $\left.N^{\circ} 1\right)$, inciso quinto, de la Constitución, con clara responsabilidad internacional para el Estado chileno, al que se imputaría una violación de las obligaciones que le impone ese tratado y del artículo 27 de la Convención de Viena sobre el Derecho de los Tratados, y, por ende, la comisión de un ilícito internacional".

Agregando dicho voto disidente que "Luego, no resultaría lógico impedir la declaración de inconstitucionalidad de las normas de un tratado, con efectos erga omnes, por importar una derogación de las mismas -como lo hace el inciso final del artículo 470 del proyecto de ley examinado-y autorizar, en cambio, la declaración de inaplicabilidad de dichas disposiciones, por acarrear una mera suspensión para la gestión concreta de que se trata, si, en uno y otro caso, se vulnera igualmente la Constitución y se genera, en idénticos términos, responsabilidad internacional para el Estado".

El Ministro Fernández Fredes, es aún más duro en la materia, precisando en su voto disidente:

"f) A juicio de este disidente, ésa es la única interpretación que se compadece con la letra y el espíritu de nuestra Constitución y que mantiene coherencia con el ordenamiento jurídico en su conjunto, toda vez que lo resuelto en este aspecto por el voto de mayoría vulnera frontalmente el compromiso internacional suscrito por el Estado de Chile al suscribir y ratificar la Convención de Viena sobre Derecho de los Tratados, de 1969, cuyo artículo 27 impide a los Estados Partes invocar las disposiciones de su derecho interno como justificación del incumplimiento de un tratado.

“g) Es más, en opinión de este discrepante lo resuelto en este aspecto por el voto de mayoría ignora que a este Tribunal Constitucional, como órgano del Estado que es, le empecen por completo los enfáticos mandamientos de los artículos $6^{\circ}$ y $7^{\circ}$ de nuestra Carta Fundamental, en el sentido de sujetarse estrictamente a la Constitución y a las normas dictadas conforme a ella (lo que incluye, por cierto, a los tratados vigentes) y de no arrogarse atribuciones que no le hayan sido expresamente conferidas, por todo lo cual se considera que un eventual fallo de esta Magistratura que acoja un requerimiento de inaplicabilidad contra una norma de un tratado vigente sería susceptible de impugnarse por una acción de nulidad de derecho público".

Cabe sostener, complementariamente, que el texto reformado de la Constitución equilibra adecuadamente, el respeto al principio de supremacía constitucional, el cual queda asegurado por el control preventivo de constitucionalidad de los tratados establecido en los numerales $1^{\circ}$ y $3^{\circ}$ del artículo 93 de la Carta Fundamental y la intangibilidad de los tratados ya ratificados, los cuales solo pueden alterarse en sus efectos 
jurídicos de acuerdo al derecho internacional como determina el artículo 54 de la Constitución reformada en 2005. Esta es la interpretación conforme a la Constitución que el fallo de mayoría no evalúa adecuadamente, dándole efecto útil y fuerza normativa en forma armónica a ambos principios constitucionales.

Puede sostenerse así que la mayoría sustenta su posición en lo que podríamos denominar una "tradición jurisprudencial", sin sustento en el derecho constitucional positivo, que desean los magistrados de la mayoría que sea mantenida, pero ello choca contra texto expreso de la Constitución que no la permite, como asimismo con el contexto y fin con el cual se concretó en la materia la reforma constitucional de 2005, ya que impide al Tribunal Constitucional por vía interpretativa hacerse de atribuciones que no le están expresamente concedidas por la Carta Fundamental, ya que ello viola el artículo $7^{\circ}$ inciso $2^{\circ}$ de la Constitución, introduciendo lo que en términos técnico jurídicos, sería una mutación constitucional.

\subsubsection{La apelación inadecuada al derecho constitucional comparado que hace el} fallo del Tribunal Constitucional

El Tribunal Constitucional en diversas oportunidades hace referencias a disposiciones constitucionales extranjeras y a fallos de tribunales constitucionales extranjeros, lo cual es legítimo para el análisis de instituciones comunes a tradiciones constitucionales comunes. Sin embargo, ello exige el mínimo cuidado de analizar previamente si estamos ante instituciones jurídicas u ordenamientos constitucionales análogos, es ilegítimo el uso descontextualizado de textos constitucionales extranjeros, sin una visión armónica y sistemática de dichos ordenamientos constitucionales, como el propio Tribunal Constitucional ha determinado en este mismo fallo y en muchos otros, las constituciones constituyen un todo unitario, donde no pueden ser analizadas algunas instituciones desconectadas del conjunto del ordenamiento, ya que ello lleva a comparaciones arbitrarias e inconsistentes. Por otra parte, es necesario justificar por qué se cita un texto constitucional extranjero y no otro que tiene opciones diferentes, lo que puede mostrar una selección arbitraria y poco cuidadosa del operador jurídico respectivo.

En este caso, el fallo se remite al derecho constitucional español en su considerando $68^{\circ}$, para hacer referencia a la institución precisada en el artículo $54 \mathrm{~N}^{\circ} 1$ inciso $5^{\circ}$ de nuestra Constitución, y luego alude a un autor español que da su opinión en el contexto del ordenamiento jurídico español, el cual es distinto del ordenamiento jurídico constitucional chileno. En efecto, el derecho constitucional español no tiene la diferenciación que nuestro texto constitucional realiza en el artículo 93 entre las atribuciones del Tribunal Constitucional para realizar control de constitucionalidad de tratados (numerales 1 y 3 ) del control reparador de constitucionalidad del numeral $6^{\circ}$, referido únicamente a preceptos legales, baste al respecto examinar solamente el artículo 161 de la Constitución española vigente al respecto. Una elemental preocupación por el contenido de los textos hubiere mostrado la diferencia evidente entre un texto constitucional que claramente distingue el control de constitucionalidad de tratados y de preceptos legales (el chileno), de otro, en que hay una referencia genérica 
a normas con fuerza de ley (España). En efecto, el artículo 161, que regula las competencias del Tribunal Constitucional español, en su literal a) determina como atribución ejercer el "recurso de inconstitucionalidad contra leyes y disposiciones normativas con fuerza de ley. La declaración de inconstitucionalidad de una norma jurídica con rango de ley, interpretada por la jurisprudencia, afectará a ésta, si bien la sentencia o sentencias recaídas no perderán el valor de cosa juzgada". Esta sola diferencia normativa marca un abismo entre el tratamiento de tratados internacionales en derecho constitucional español y chileno, como asimismo muestra la falta de prolijidad de hacer comparación jurídica entre instituciones que operan en marcos jurídicos disímiles y con disposiciones claramente distintas, lo que solo puede demostrar las diferentes opciones de los respectivos constituyentes.

Otra cosa distinta es la argumentada por el fallo en su considerando $69^{\circ}$, apelando a los dichos del profesor de Derecho Internacional, Francisco Orrego Vicuña, durante la tramitación de la ley que motiva el presente control de constitucionalidad, "en muchos sistemas judiciales se permite tal inaplicabilidad por contravenir el tratado, por ejemplo, las garantías individuales o el debido proceso del particular afectado"; en efecto, esta es una materia distinta, ya que en este ámbito estamos considerando derechos fundamentales o derechos humanos, materia que se rige por el principio favor persona y el principio de progresividad, propios de la interpretación en materia de derechos humanos, por tanto, el órgano de jurisdicción constitucional debe velar por que la norma de derecho que se aplique sea aquella que mejor proteja el derecho, ya sea esta de derecho constitucional (derecho interno) o de derecho internacional (norma contenida en tratado, derecho consuetudinario internacional o principios imperativos de derecho internacional), en este caso hay una aplicación de la norma que mejor protege los derechos, la que se encuentra ampliamente consagrada por el derecho y las jurisdicciones internacionales de derechos humanos, basta analizar el artículo 29 literal b) de la Convención Americana sobre Derechos Humanos ${ }^{40}$ y la jurisprudencia de la Corte Interamericana de Derechos Humanos, ${ }^{41}$ como ha sido expresamente reconocido por la jurisprudencia de nuestro Tribunal Constitucional en el caso de "La píldora del día después". ${ }^{42}$

\subsection{La peligrosa apertura a la acción de inconstitucionalidad de tratados internacionales}

Es necesario precisar que al abrir el fallo una posible acción de inaplicabilidad por inconstitucionalidad en los términos previstos en el artículo $93 \mathrm{~N}^{\circ} 6$ de la Constitu-

40 El mismo principio está reconocido expresamente en el Pacto Internacional de Derechos Civiles y Políticos de Naciones Unidas, en su artículo 52, en el Protocolo Adicional de la Convención Americana sobre Derechos Humanos en materia de Derechos Económicos, Sociales y Culturales o Protocolo de San Salvador, artículo $4^{\circ}$; la Convención sobre la Eliminación sobre todas las Formas de Discriminación contra la Mujer, artículo 23; y la Convención sobre los Derechos del Niño, artículo 41, entre otras.

41 Dicho principio es aplicado por la Corte Interamericana desde su Opinión Consultiva $\mathrm{N}^{\circ} 7 / 85$.

42 Sentencia del Tribunal Constitucional, Rol N ${ }^{\circ} 740-07$, de dieciocho de abril de dos mil ocho, considerando $69^{\circ}$. Lo destacado es nuestro. La misma referencia es efectuada en su Sentencia del Tribunal Constitucional, Rol 1361-09, de trece de mayo de dos mil nueve, considerando $73^{\circ}$. 
ción, si ella es acogida, produce en cascada el efecto de abrir la acción pública de inconstitucionalidad, si se asume como lo hace el fallo que los tratados son equivalente normativos a las leyes o preceptos legales, es obvio señalar que la fuerza normativa del artículo $93 \mathrm{~N}^{\circ} 7$, se encuentra por encima de las disposiciones de la LOC del Tribunal Constitucional que impiden dicha acción en materia de tratados, siendo a tales efectos inconstitucionales por contravenir directamente el texto claro de la disposición constitucional, lo que obviamente, de producirse vulnera abierta y claramente los artículos 26 y 27 de la Convención de Viena sobre Derecho de los Tratados, tema que no fue analizado por el Tribunal Constitucional y que es una consecuencia no querida de su fallo. Todo ello si se acogiera hipotéticamente una acción de inaplicabilidad por inconstitucionalidad en la materia.

\subsection{El Tribunal Constitucional y la hipótesis de ley interpretativa constitucional del artículo 47 B del proyecto adecuatorio de la LOC del Tribunal Constitucional}

El Tribunal Constitucional, en esta sentencia, en el proceso de control preventivo del texto de ley adecuatorio de la LOC del Tribunal Constitucional ha determinado en su considerando $12^{\circ}$ que "el artículo 38 bis, inciso primero, que el artículo único, $N^{\circ} 43$, del proyecto agrega a la Ley $N^{\circ} 17.997$, aclara el sentido del inciso cuarto del artículo 93 de la Constitución en cuanto establece que el requerimiento respectivo ha de ser 'formulado antes de la promulgación de la ley' y debe considerarse como una norma interpretativa constitucional".

En tal perspectiva, cabe preguntarse porque no realizó el mismo razonamiento acerca de la consideración como ley interpretativa de la Constitución del artículo 47 b) del proyecto, el que determina que "de conformidad con el número 1) del artículo 54 de la Constitución Política de la República, no procederá la inaplicabilidad respecto de tratados internacionales ratificados por Chile y que se encuentren vigentes". En la medida que si se cumplen los requisitos formales determinados por el texto de la Carta Fundamental y no afecta el contenido expreso de ninguna disposición constitucional, el legislador tiene el legítimo derecho de expresar el sentido y alcance del artículo $54 \mathrm{~N}^{\circ} 1$ de la Constitución. Sentido y alcance que predomina sobre la voluntad del Tribunal Constitucional, ya que este último debe efectuar un análisis de conformidad con la Constitución, en el respeto del principio de corrección funcional.

La interpretación conforme a la Constitución lleva a una interpretación favor legis en el ámbito del derecho interno, y de favor convenciones, en el plano del derecho internacional, vale decir, opera una presunción de constitucionalidad de la obra del legislador y del gobierno al aprobar una ley o un tratado internacional. ${ }^{43}$ Esta presun-

43 Sentencia del Tribunal Constitucional de fecha 4 de agosto de 2000 , Rol $\mathrm{N}^{\circ} 309$, sobre Convenio $\mathrm{N}^{\circ} 169$ sobre "Pueblos Indígenas y Tribales en países independientes", donde el Tribunal Constitucional hace un esfuerzo de interpretación conforme a la Constitución, declarando constitucional el acuerdo aprobatorio del Convenio. 
ción de constitucionalidad lleva a que el juez constitucional solo pueda declarar inconstitucionales los preceptos legales cuando exista una contradicción manifiesta entra la Carta Fundamental y la ley, ya que en caso de duda la presunción favorece la constitucionalidad del precepto legal. Ello es más patente aún en las leyes interpretativas de las disposiciones constitucionales. Nuestro Tribunal Constitucional ha asumido plenamente este postulado, así a manera ejemplar, en su sentencia sobre el Convenio $\mathrm{N}^{\circ} 169$ sobre Pueblos indígenas y tribales en países independientes, sostuvo el principio de conformidad con la Constitución entre los principios de interpretación constitucional que aplicaría: "Que, el primero denominado de "presunción de constitucionalidad' por algunos y 'presunción de legitimidad' por otros, vinculándose estrechamente, con el que unos últimos denominan 'de conformidad con la Constitución'. Sin embargo, cualquiera que sea la denominación, lo fundamental de este principio consisten en que se presumen válidas y legítimas las normas aprobadas por los Poderes del Estado y que solo resulta prudente y aconsejable declarar su inconstitucionalidad cuando los sentenciadores Ileguen a la íntima convicción que la pugna entre la norma en análisis y la Constitución es clara, resultando imposible armonizarla con ella. Este principio tiene muchos fundamentos, pero, por ahora, cabe solo señalar dos: la separación de poderes y el recíproco respeto que los distintos órganos del Estado se deben entre sí y, tratándose de leyes, lo difícil que resulta reemplazar la norma expulsada del ordenamiento jurídico por la declaración de inconstitucionalidad, por las complejidades propias del proceso de formación de la ley. Este principio ha sido constantemente aplicado por este tribunal como lo evidencian las sentencias dictadas en las causas Roles $N^{\circ} 257,271,293$ y 297, entre otras". ${ }^{44}$

Por otra parte, el Tribunal Constitucional chileno ha aplicado el principio de corrección funcional en diversas oportunidades. ${ }^{45}$ Ello exige de los jueces constitucionales un judicial self-restreint o autocontención, que les exige evitar invadir el campo del legislador o de la política para mantenerse en sus funciones dentro de criterios estrictamente jurídicos. Ello implica reconocer al legislador dentro del marco constitucional, el amplio margen para adoptar en cada caso las políticas que considere más adecuadas y oportunas. Una “autocontención prudente", en la que puede distinguirse la autocontención política, que evita involucrarse en cuestiones políticas y la autocontención funcional, que surge del cuidado de no extralimitarse en las resoluciones a la respuesta a las demandas planteadas. Por otra parte, también la autocontención implica al juez respetar la separación de poderes y que no invade competencias correspondientes a otros órganos estatales, que no se convierte en legislador positivo ni en poder constituyente, para lo cual no tiene jurisdicción ni competencia.

44 Sentencia del Tribunal Constitucional, Rol $\mathrm{N}^{\circ} 309$ de fecha cuatro de agosto de dos mil dos, considerando $2^{\circ}$ del Capítulo $1^{\circ}$.

45 Sentencia del Tribunal Constitucional; Rol $N^{\circ}$ 790-07, de 11 de diciembre de 2007, considerando vigesimoctavo, párrafo final. Ver además sentencias anteriores; rol $\mathrm{N}^{\circ} 551$, de 8 de agosto de 2006; Rol $\mathrm{N}^{\circ}$ 522, de fecha 16 de agosto de 2006; Rol $\mathrm{N}^{\circ} 503$ de 8 de agosto de 2006; Rol $\mathrm{N}^{\circ} 498$ de 19 de junio de 2006. 
A lo anteriormente señalado debemos agregar, que en el segundo informe de la Comisión de Constitución, Legislación y Justicia del Senado sobre la Ley adecuatoria de la Ley Orgánica Constitucional del Tribunal Constitucional, se deja constancia que el señor Presidente del Tribunal Constitucional señaló que, en materia de control de constitucionalidad de tratados internacionales, "sin que ello implique adelantar juicio sobre el punto, hay tres posturas disímiles en el Tribunal. En primer lugar, hay ministros que consideran que una norma de ese tipo tiene el carácter de interpretativa de la Constitución Política de la República, por lo que debe ser aprobada con el quórum que en tal carácter le corresponde y debe ser objeto de control preventivo de constitucionalidad. La segunda postura señala que la norma es directamente inconstitucional, por lo que debe ser rechazada, lo que implicaría que los tratados constitucionales perfectamente pueden ser objeto de acciones de inaplicabilidad y de inconstitucionalidad. La tercera postura sostiene que esta norma es perfectamente constitucional, toda vez que acata la regla del derecho internacional público que prohíbe a los Estados contratantes infringir un tratado suscrito, bajo el pretexto de que prima su ordenamiento interno".

Es curioso que pese a que el legislador, conociendo las posiciones al interior del Tribunal Constitucional y dejando constancia de ellas en este segundo informe, por lo mismo haya insistido en la versión aprobada del proyecto, en el $47 \mathrm{~B}$ del proyecto adecuatorio de la LOC del Tribunal Constitucional, en una norma que desactivaba la interpretación contraria que tenían algunos miembros del Tribunal Constitucional, y esta línea interpretativa no se haya tenido en consideración como tal en el Tribunal Constitucional.

La pregunta que nos hemos efectuado no tiene respuesta en la sentencia del Tribunal Constitucional analizada, ya que los magistrados de la mayoría en este fallo no evaluaron ni argumentaron sobre dicha alternativa perfectamente legítima y válida del legislador, como intérprete auténtico de la Constitución, cuya atribución está expresamente contemplada en el artículo 66 de la Constitución, avalada además por la legitimidad de la representación ciudadana que tiene el Congreso Nacional.

El mismo Tribunal Constitucional ha señalado en relación al alcance de las leyes interpretativas que: "Por medio de una ley interpretativa sólo cabe proporcionar claridad o precisión a la redacción de una norma constitucional, cuando su propio texto sea susceptible de originar confusión o desentendimiento, para asegurar con esa interpretación su correcta, uniforme, armónica y general aplicación" (Rol 158/1992).

Como podría negarse la claridad interpretativa que proporciona el artículo 47 B del proyecto adecuatorio de la LOC del Tribunal Constitucional a la interpretación del artículo $93 \mathrm{~N}^{\circ} 6$, cuando este mismo fallo muestra la diversidad y dispersión de interpretaciones de los mismo magistrados que integran el Tribunal Constitucional (seis votos contra cuatro, con el agravante que uno de los votos de la mayoría ya no es miembro del Tribunal por haber caducado su periodo y el ministro entrante ha mantenido un criterio similar al establecido por los cuatro ministros de la minoría, con lo cual ella dejaría de ser tal). 


\section{EFECTOS JURÍDICOS DEL FALLO EN LA MATERIA EN ANÁLISIS}

El análisis crítico del fallo realizado, no impide pese a su debilidad argumental y su inadecuado uso del derecho extranjero, que tenga el carácter de una sentencia, respecto de la cual no procede recurso alguno como determina el artículo 94 inciso $1^{\circ}$ de la Constitución, como asimismo, que la disposición del artículo 47 B del proyecto adecuatorio de la LOC del Tribunal Constitucional, declarada inconstitucional, no podrá convertirse en ley, de acuerdo al inciso $2^{\circ}$ del artículo 94 ya citado.

Ello implica que simplemente no habrá la norma que quiso establecer el legislador en cuanto intérprete auténtico de la Constitución o como legislador orgánico constitucional, según la interpretación que se dé al texto del artículo 47 b) del proyecto, declarado inconstitucional. El que no exista la norma no soluciona el problema de una interpretación auténtica, ya que su ausencia generará una inseguridad jurídica muy grave, ya que deja abierto el tema a la interpretación que de acuerdo a sus propios criterios sigan realizando los magistrados constitucionales, ya que podrán conformarse nuevas mayorías diferentes en el Tribunal Constitucional, las cuales pueden modificar sus propios precedentes fundadamente, teniendo presente además que en Chile el precedente no es obligatorio.

El mismo legislador se negó a darle al Tribunal Constitucional el carácter de "supremo intérprete de la Constitución" como asimismo dar carácter vinculante para los demás órganos del Estado a sus sentencias, como quedó constancia en el segundo informe sobre la ley adecuatoria parcialmente analizada en este artículo. En efecto, en el Segundo Informe de la Comisión de Constitución, Legislación y Justicia del Senado, señalándose que "todos los jueces interpretan y aplican la Constitución, no sólo el Tribunal Constitucional. Apartarse de este criterio implicaría otorgar a las sentencias de este último un poder vinculante que no tienen, salvo el caso excepcionalísimo de la declaración de inconstitucionalidad del número $7^{\circ}$ del artículo 93, ya que la regla general es que los fallos judiciales sólo surtan efectos entre las partes en contienda”.

Por otra parte, como todos sabemos, las sentencias del Tribunal Constitucional carecen de imperio, lo que no es un problema menor; a ello debe agregarse el análisis del tema de la cosa juzgada que emana de tales sentencias, sobre lo cual se abren hipótesis ampliamente debatibles.

El criterio adoptado por nuestro ordenamiento mantendrá una debilidad crónica de nuestro sistema de jurisdicción constitucional, la existencia y mantención de diversos parámetros y criterios de control, tal como lo hemos podido explicitar en este trabajo, lo que afecta la seguridad jurídica y la igualdad en la aplicación del ordenamiento jurídico.

La parte de la sentencia sobre la Ley adecuatoria de la LOC del Tribunal Constitucional, analizada críticamente, muestra que dicha sentencia más que cerrar un debate, ella lo incentivará en la comunidad académica nacional del derecho constitucional. 